\title{
Stratigraphy and sedimentology of distal-alluvial and lacustrine deposits of the western-central Ebro Basin (NE Iberia) reflecting the onset of the middle Miocene Climatic Optimum
}

This paper is dedicated to the memory of our colleague and friend Joaquín Villena Morales, who passed away recently. He was an enthusiastic pioneer of "Tectosedimentary Units", working in the Cenozoic of the Ebro Basin

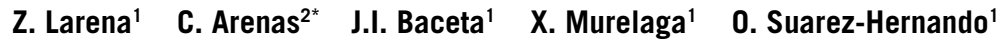

\author{
1Department of Stratigraphy and Palaeontology. Science and Technology Faculty. University of the Basque Country/EHU \\ Barrio Sarriena, s/n. 48940 Bizkaia, Spain. Larena E-mail: larenamartin9@gmail.com Baceta E-mail: juanignacio.baceta@ehu.eus \\ Murelaga E-mail: xabier.murelaga@ehu.eus
}

${ }^{2}$ Stratigraphy Division. Department of Earth Sciences, Institute for Research on Environmental Sciences of Aragón (IUCA) and GEOtransfer Group. University of Zaragoza

Calle Pedro Cebuna, 12. 50009 Zaragoza, Spain. E-mail: carenas@unizar.es

${ }^{*}$ Corresponding author

A B S T R A C T

Stratigraphic and sedimentological study of distal alluvial and lacustrine deposits in the Plana de la Negra-Sancho Abarca area (western-central Ebro Basin, NE Iberia) within the early and middle Miocene allows five main lithofacies to be characterized and mapped within two tectosedimentary units, construction of a sedimentary facies model and discussion on allogenic controls on sedimentation. In this area, the boundary between tectosedimentary units T5 and T6 appears to be conformable and is marked by the change from dominant clastics to carbonates. Correlation of the studied outcrops with nearby sections that already had magnetostratigraphic and biostratigraphic data allows the studied succession to be dated from C5Dr to C5Cn (Burdigalian-Langhian), placing the boundary T5/T6 at ca.16.1-16.05Ma.

Seven vertical facies sequences document deposition of distal alluvial clastics and palustrine and lacustrine carbonates. Sandstones and mudstones represent low-sinuosity channels and lateral and terminal splays by unconfined flows runnig across the alluvial plain, associated to the Pyrenean-derived Luna fluvial system. The carbonates contain charophytes, ostracods, bivalves and gastropods, indicating deposition in $2-4 \mathrm{~m}$ deep lakes. Laminated carbonate facies record reworking of shore carbonates and the influx fine-siliciclastic sediment offshore. Abundant bioturbation and desiccation features indicate episodic submergence and subaerial exposure.

Four main episodes of alluvial and associated palustrine/lacustrine facies belt shifts are identified. Alluvial deposition in the studied T5 unit is related to low lake level conditions, rather than to a Pyrenean uplift. The maximum extent of the freshwater carbonates occur at the base of unit T6. This is consistent with conditions of increasing humidity of the Middle Miocene Climatic Optimum. 


\section{INTRODUCTION}

Lacustrine deposits are shown to be excellent indicators of tectonic and climatic change (Arenas and Pardo, 1999; De Wet et al., 1998; Gierlowski-Kordesch, 2010; Kelts and Talbot, 1990). Given the small size of lake systems compared to ocean basins, and their intimate connection with coeval drainage/catchment areas, lake basins are very sensitive to climate and tectonic changes at different time scales (Bohacs et al., 2000; Vázquez-Urbez et al., 2013). Catchment area tectonics and lithology have a direct influence on sediment flux into the lake basin, lithofacies characteristics and facies evolution (Carroll and Bohacs, 1999; Davis et al., 2008). At the same time, the type and amount of sediment in the lake basin is also controlled by climate, which ultimately drives lake level variations through changing evaporation and precipitation (AlonsoZarza et al., 2012; De Wet et al., 1998; Platt and Wright, 1991).

The Ebro basin is one of the largest cenozoic intermontane basins in the Iberian Peninsula that developed during the Paleogene and Neogene, as a result of the alpine collision of the Iberian and Eurasian plates. The OligoceneMiocene continental deposits of the Ebro Basin (Fig. 1A) formed in alluvial and fluvial systems that were connected to lacustrine systems (Arenas and Pardo, 1999; Muñoz et al., 2002; Valero et al., 2014). Coarse to fine detrital deposits originated in the marginal alluvial systems, and carbonate and evaporitic deposits and minor coals (Cabrera and Sáez, 1987) formed in the lacustrine systems. Carbonate deposits, mostly limestones and marlstones, consist of varied palustrine and lacustrine facies that were coeval with alluvial plain deposits. The carbonates crop out across morphological uplands in the basin centre that are known locally as "sierras" and "muelas" or "planas". One of these uplands, the Plana de la Negra-Sancho Abarca, within the Bardenas Reales area (Fig. 1A, B) is the focus of this study. A series of recent works in this area yielded reliable new magnetostratigraphic, biostratigraphic and paleoecologic data (Larrasoaña et al., 2006; Martínez-García et al., 2014; Murelaga et al., 1997; Ruiz-Sánchez et al., 2012, 2013; Suarez-Hernando, 2017). These works have provided a chronostratigraphic framework and allow the comparison of environmental and climatic conditions over time. Navarro-Jiménez et al. (2011) presented a stratigraphic study of the area, establishing the boundary between two tectosedimentary units (T5 and T6) at 16.3Ma, on the basis of magnetostratigraphic results obtained by Larrasoaña et al. (2006). Detailed stratigraphic analysis and correlation with neighbouring areas that have precise datings (i.e. those of Pérez-Rivarés, 2016; Suarez-Hernando, 2017) remains to be confirmed. This paper presents a sedimentological study aiming to assess the evolution of facies and environmental conditions through time.
This work focuses on stratigraphic and sedimentological analysis of the distal alluvial and lacustrine-palustrine deposits of the Plana de la Negra-Sancho Abarca area in order to: i) provide a precise stratigraphic framework with absolute chronology for the Miocene of this region and refine the stratigraphic framework, and ii) reconstruct the evolution of the sedimentary facies environments through time, taking into account the available palaeoecological data. A discussion on the wider environmental controls of tectonics and climate on sedimentation is presented, with emphasis on the middle Miocene Climate Optimum (MMCO; $f f$. Zachos et al., 2001 among others).

\section{GEOLOGICAL SETTING}

The study area is located in the western-central sector of the Ebro Basin, in NE Iberian Peninsula (Fig. 1A). The Ebro Basin formed during the Paleogene as a consequence of the convergence of the Iberian and Eurasian plates. It represents the last evolutionary stage of the south Pyrenean foreland basin (Muñoz et al., 2002; Riba et al., 1983). The uplift of three confining mountain ranges (the Pyrenees to the north, the Catalan Coastal Ranges to the southeast and the Iberian Range to the south and southwest) defined the outlines of the basin and its sources of terrigenous sediments.

During Paleocene to middle Eocene times the basin recorded successive phases of marine and continental sedimentation. By the late Eocene, the basin had lost connection with the ocean (Costa et al., 2010) and became a large endorheic depression which was hydrologically isolated at least until middle Miocene times (Muñoz et al., 2002; Riba et al., 1983). The basin's current structure and boundaries were acquired between late Oligocene and middle Miocene times, reflecting the emplacement of the youngest south Pyrenean and Iberian thrust systems in the Marginal and External Sierras and Sierra de Cantabria, and Cameros-Demanda, respectively (Fig. 1A). From the middle Miocene onwards, a basin outflow opened into the Mediterranean Sea, and since then the basin has been subject to erosion (Arasa and Cabrera, 2018; Babault et al. 2006; García-Castellanos et al., 2003; Vázquez-Urbez et al., 2003, 2013).

\section{Stratigraphic context}

Regional studies indicate that the sedimentary infill of the Ebro Basin is arranged into eight stratigraphic genetic units (Tectosedimentary Units or TSUs, named T1 to T8; Muñoz et al., 2002; Pardo et al., 2004). The ages of these TSUs have been determined from vertebrate fossil assemblages (data summarized in Agustí et al., 2011; Murelaga et al., 2008; Pardo et al., 2004; Ruiz-Sánchez 


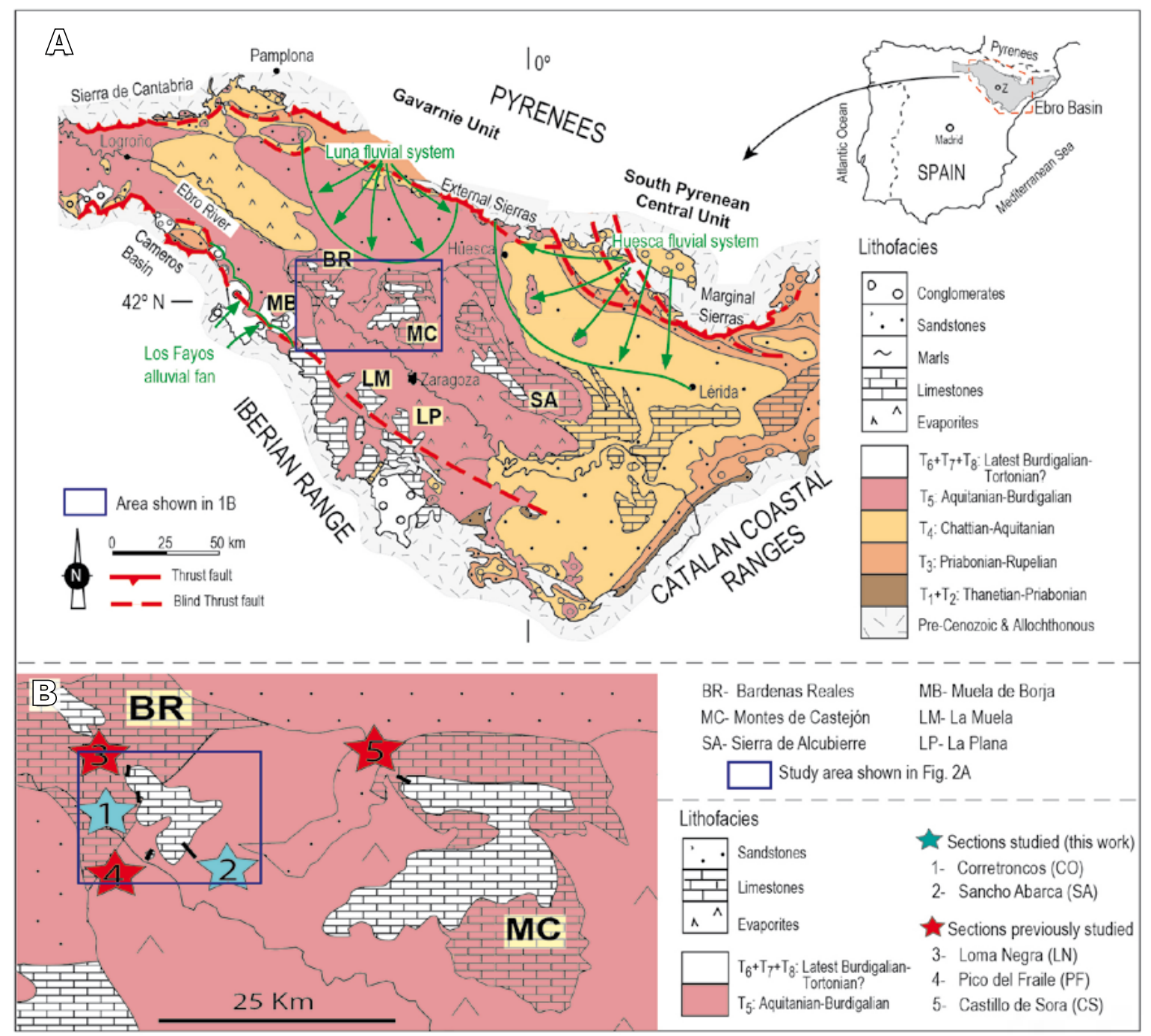

FIGURE 1. A) Geological setting of the studied area (Plana de la Negra-Sancho Abarca, blue frame included in Bardenas Reales) in the westerncentral sector of the Ebro Basin. The Luna and Huesca fluvial systems, as named by Hirst and Nichols (1986). B) Enlarged map showing the location of the studied area, with sections measured herein, as well as location of sections from other authors that are integrated in this study. Map adapted from Muñoz et al. (2002) and Pérez-Rivarés et al. (2018).

et al., 2013; Suarez-Hernando, 2017) and, more recently, by means of magnetostratigraphic studies on Oligocene and Miocene sediments (Barberà et al., 2001; Larrasoaña et al., 2006; Oliva-Urcia et al., 2019; Pérez-Rivarés et al., 2018; Valero et al., 2014).

The upper Oligocene to middle Miocene is represented by fluvial and alluvial conglomerates, sandstones and mudstones, grading into lacustrine carbonate and sulphate deposits (limestones, marls and gypsum) in the basin centre (Fig. 2) (Pardo et al., 2004).

The succession outcropping in the study area (Plana de la Negra and Sancho Abarca; Figs. 1B; 3) belongs to units T5 and T6 (Navarro-Jiménez et al., 2011; Pardo et al., 2004). Studies elsewhere in areas of the basin indicate that Unit T5 is Ramblian-Aragonian in age (Burdigalian; chrons C6An-C5Cn; Pérez-Rivarés, 2016), and T6 is early to middle Aragonian in age (latest Burdigalian-Langhian; chrons C5Cn-C5AD, Pérez-Rivarés, 2016). Strata of both units are horizontal to gently southward dipping up to $3^{\circ}$.

Unit T5 consists of mudstones with sandstone and limestone intercalations. The unit crops out extensively at the foothills of the Plana de la Negra-Sancho Abarca upland. Unit T6 is made up of thick limestone succesions with marlstone and mudstone interbeds. The boundary between units T5 and T6 is conformable and marked by an abrupt change from a mudstone succession with interbedded sandstone and limestone strata to a succession dominated by lacustrine limestones (Larena-Martin, 2019). The T5/ T6 boundary is generally conformable throughout the basin 


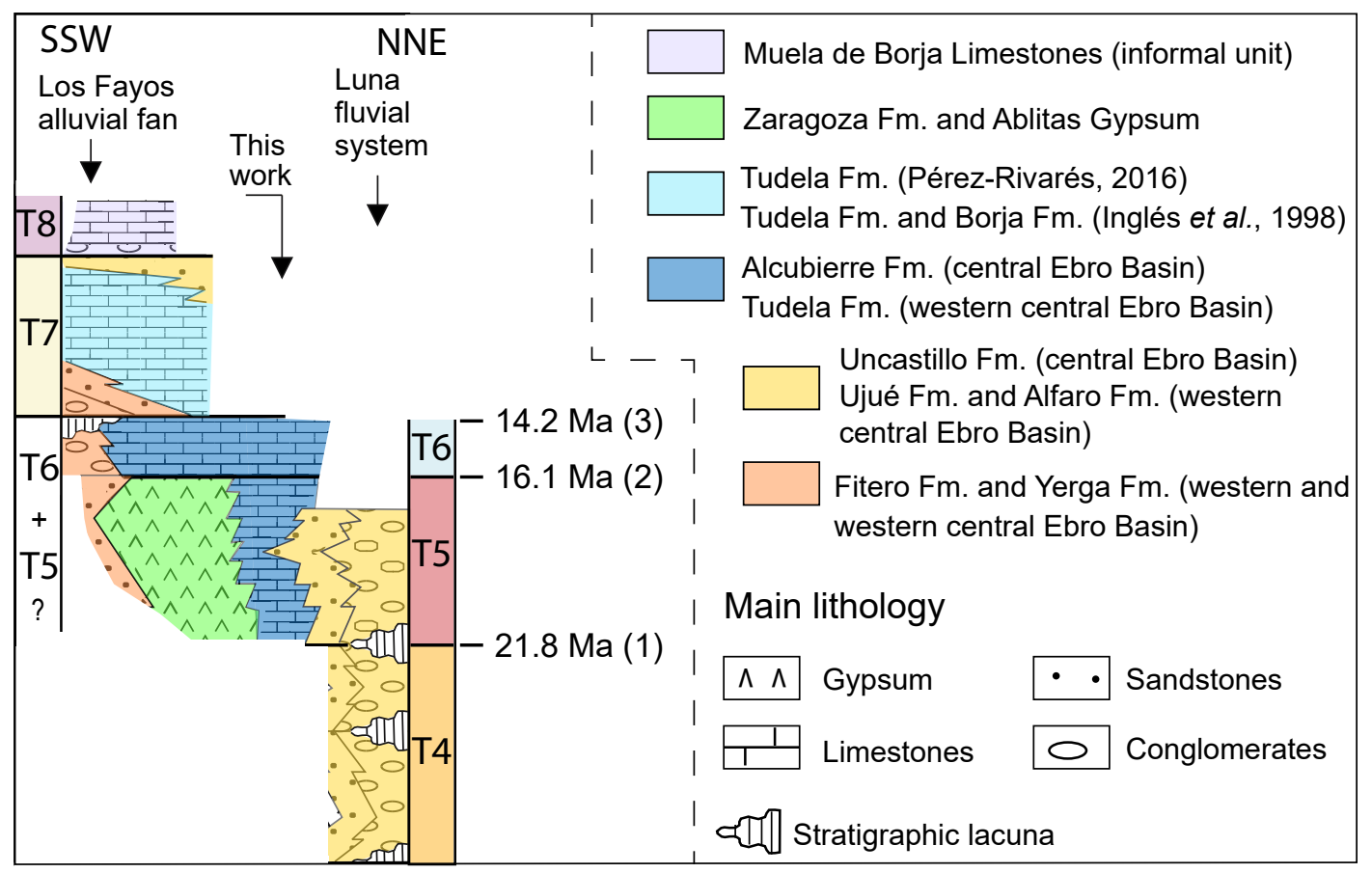

FIGURE 2. Tectonosedimentary units (from Muñoz et al., 2002 and Pérez-Rivarés et al., 2018) and lithostratigraphic units (from several authors; see Muñoz et al., 2002) across the central and central-western part of the Ebro basin. See Figure 1 for location of alluvial fans. (1) Age from Oliva et al. (2019); (2) and (3) Ages from Pérez-Rivarés (2016).

centre, with diachrony up to $0.28 \mathrm{ka}$ (see discussion by PérezRivarés et al., 2018), and locally is unconformable, i.e. at the basin margins in the southwesternmost and southeast sectors of the Ebro Basin. This boundary is not known at the northern central basin margin (i.e. the age of rocks unit T5 is unknown) (Pardo et al., 2004; Pérez-Rivarés, 2016).

Lithostratigraphically, the studied deposits belong to the Tudela Formation (Astibia et al., 1995; Crusafont et al., 1966; Larrasoaña et al., 2006; Riba, 1955), which represents the early to middle Miocene in the Navarra-La Rioja NW sector of the Ebro Basin, and unconformably overlies the Oligocene to lower Miocene Lerín Formation, which is equivalent to the Zaragoza Formation in the basin centre (Fig. 2).

The Tudela Formation passes laterally through complex interfingering into coarse alluvial successions of the Ujué, Uncastillo and Alfaro Formations at the northern and southern basin margins (Castiella, 1977; Soler and Puigdefábregas, 1970). Towards the basin centre and to the east and southeast of the study area, the Tudela Formation passes laterally into the carbonate- and evaporite-dominated series of the Alcubierre and Zaragoza Formations (Fig. 2) (Muñoz et al., 2002).

The Tudela Formation has been interpreted as representing distal alluvial deposits sourced from the
Pyrenean and Iberian ranges, to the north and south respectively, the related fluvial systems draining into a stable freshwater lake across laterally extensive palustrine fringes (Larrasoaña et al., 2006).

\section{METHODOLOGY AND TECHNIQUES}

Two stratigraphic sections were measured and drawn up on a 1:100 scale. Correlation between these sections and throughout the studied area is based on cartographic (detailed mapping of units and key surfaces), lithological and textural criteria (e.g. sequential sedimentary evolution through time and presence of sharp lithological changes through the sequences) (see Fig. 3A). Following the methodology of the tectosedimentary analysis (Pardo et al., 1989), stratigraphic genetic units named TectoSedimentary Units (TSUs) have been characterised and correlated with nearby sections which had been dated based on magnetostratigraphic and paleontological studies.

Sedimentary structures including cross bedding and lamination, and channel orientations were used to deduce palaeocurrent directions in the clastic deposits.

A total of 140 representative samples were collected from all of the lithologies (limestones, marls, mudstones and sandstones). 90 thin sections were prepared for 


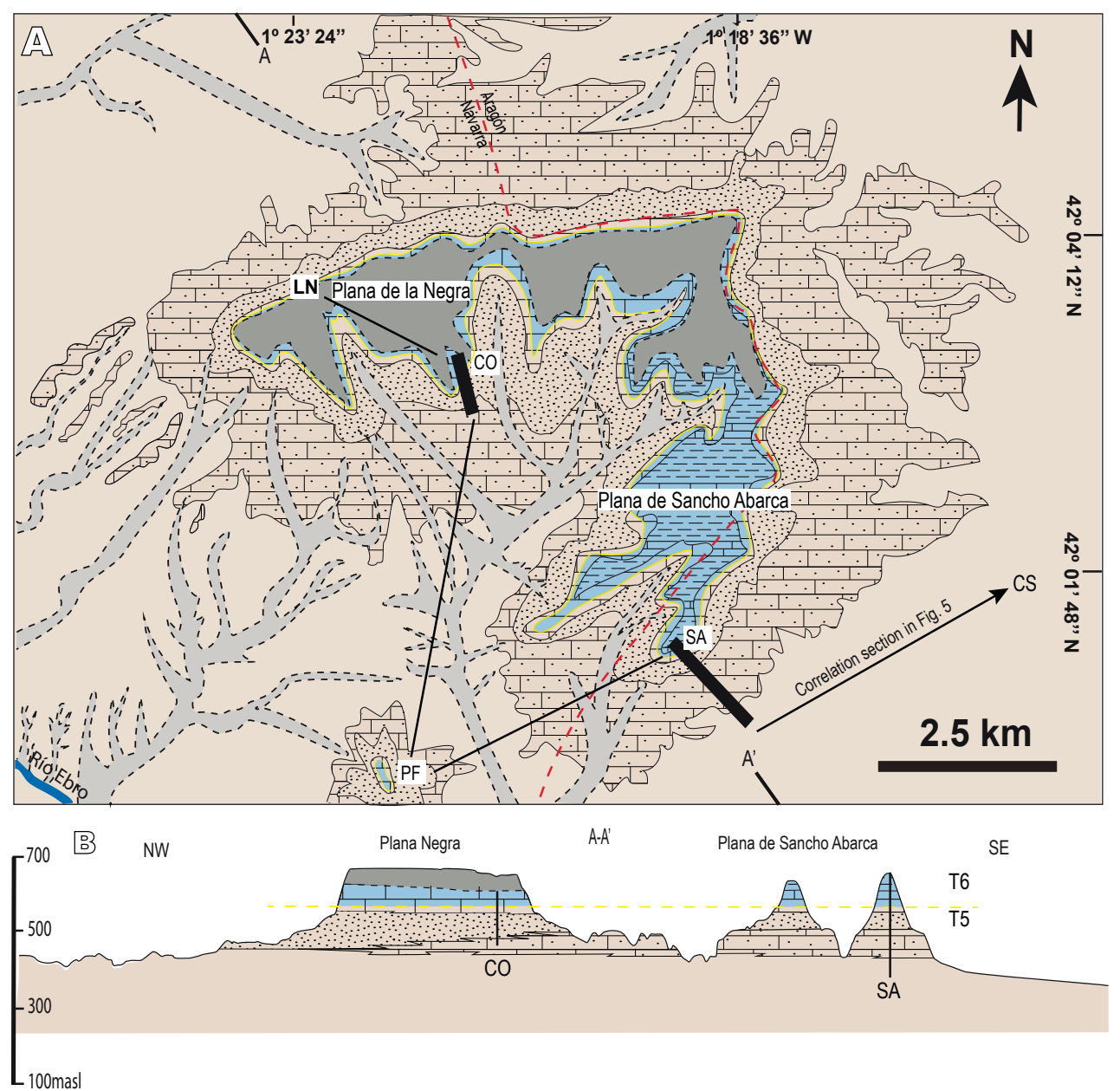

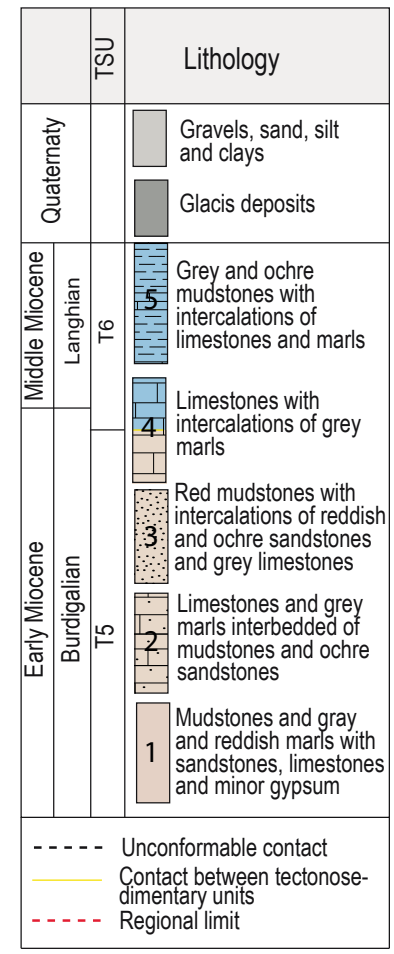

Stratigraphic sections

CO: Corretroncos

SA: Sancho Abarca

PF: Pico del Fraile

LN: Loma Negra

CS: Castillo de Sora

FIGURE 3. A) Geological map of the studied area (Plana de la Negra-Sancho Abarca) showing tectonosedimentary units (TSU T5 and T6) and lithofacies (numbered 1 to 5 , as in the text). Lines between sections represent correlation shown in Figure 6 . B) Synthetic geological cross section across the study area ( $A-A^{\prime}$ in Figure $\left.2 A\right)$.

petrographic and textural analyses. Nomenclature used for the diverse carbonate textures followed classification of Dunham (1962), with modification by Embry and Klovan (1971), and the classification Petijhon et al. (1973) for siliciclastic deposits.

Ten fine-grained mudstone and marly mudstone samples were analysed for calcium carbonate content of fine-grained sediments, using a manocalcimeter (Geoservices, France) based on the method of Scheibler, at the stratigraphy laboratory of the University of Zaragoza (Spain).

\section{STRATIGRAPHY}

Based on the two measured sections and stratigraphic information gathered from intervening field areas, the Miocene succession in the Plana de la Negra-Sancho Abarca area comprises five main lithofacies (i.e. mappable facies associations, $c f$. Bates and Jackson, 1985), which are traceable as laterally continuous units through the study area (Figs. 3A, B; 4).

Lithofacies 1 consists of grey and red mudstones and marls, with interbedded sandstones, limestone and rare gypsum beds. This lithofacies makes the older T5 deposits in the studied area, which are $13 \mathrm{~m}$ thick at the base of the Sancho Abarca section (SA).

Lithofacies 2, 3 and 4 are present in both measured sections. Lithofacies 2 is formed of grey limestones and marls with interbedded yellowish to ochre mudstone and thin and laterally discontinuous ochre sandstone strata. This lithofacies forms the base of the succession in section $\mathrm{CO}$ and is up to $37 \mathrm{~m}$ thick in section SA.

Lithofacies 3 is composed of thick red and orange mudstones with interbedded reddish and ochre sandstone strata and very ocassional grey to ochre limestone beds. This unit is $60 \mathrm{~m}$ thick at SA section and $102 \mathrm{~m}$ thick at CO section. 


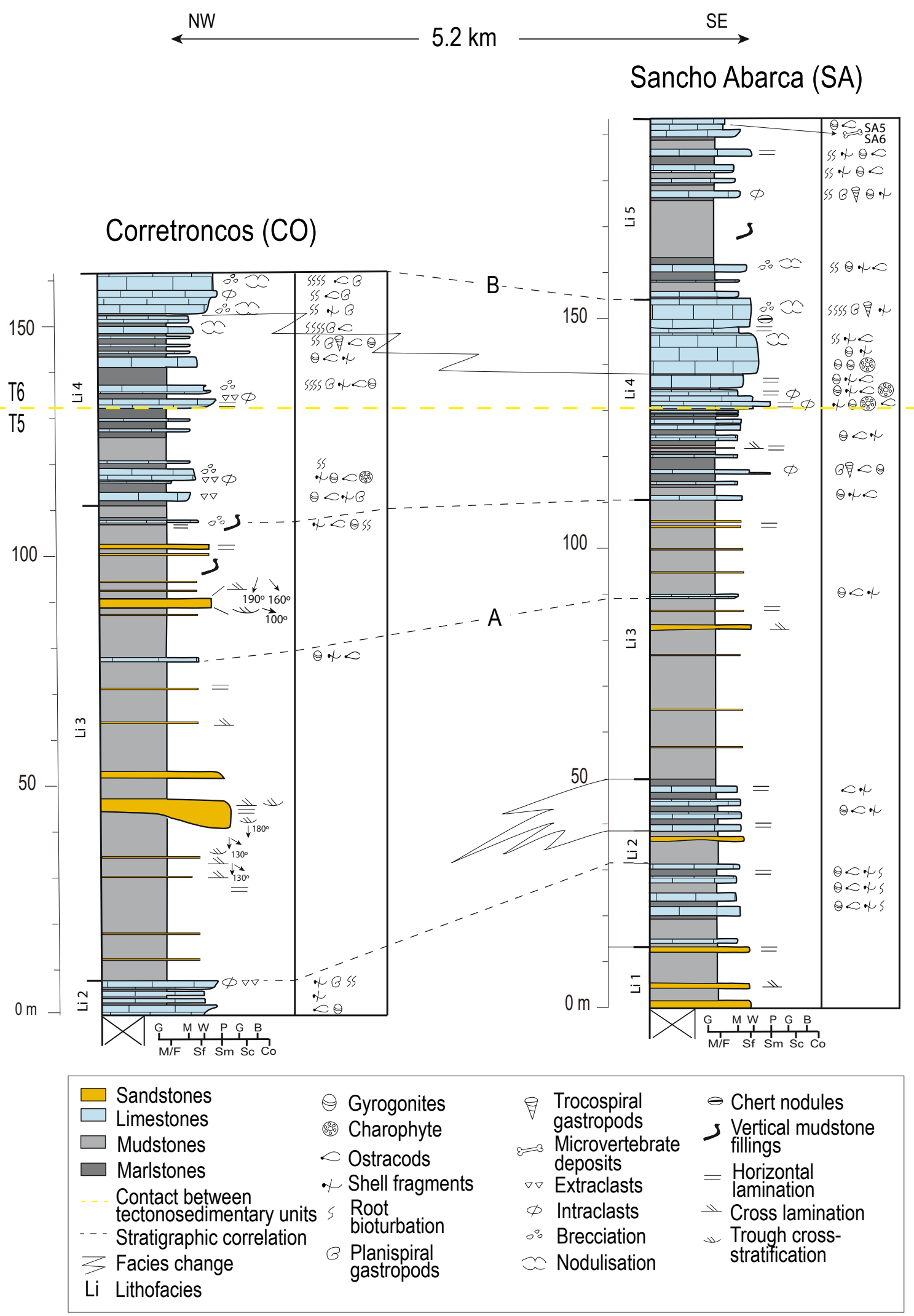

FIGURE 4. Stratigraphic lithologs of the two sections measured in this study (location in Figure 2A). Correlation is based on key surfaces A and B, and the T5/T6 boundary. Lithofacies are also indicated (Li1 to Li5). Symbols at the base of sections: M: Mudstone; W: Wackestone; P: Packestone; G: Grainstone; F: Fines (claystone and siltstone); M: Marls; Sf, Sm and Sc: fine, medium and coarse sandstone; Co: Conglomerate. 
Lithofacies 4 consists of grey limestones with interbedded grey marls and less abundant grey mudstones. The lower part of this lithofacies is a $20 \mathrm{~m}$ thick interval dominated by marls in section SA, while in section $\mathrm{CO}$ is a $22 \mathrm{~m}$ thick interval dominated by mudstones and marls and marlstones. The rest of the lithofacies is formed by thick deposits of limestones, $25 \mathrm{~m}$ thick in section SA and $30 \mathrm{~m}$ thick in section $\mathrm{CO}$.

Lithofacies 5 is only present in the southern portion of the studied area (section SA). It occurs as a $37 \mathrm{~m}$ thick succession of grey and ochre mudstones with interbedded grey limestones and less common grey marls (in section SA).

The main datum for correlation between the two studied sections was the T5/T6 boundary and a distinct limestone bed described as surface B (Fig. 4). This boundary lies within Lithofacies 4 , being set at the base of the dominant limestone succesion. Thus, in the Plana de la NegraSancho Abarca area, the T5/T6 boundary is recognized by a sharp transition from dominant mudstones and marls to a limestone-dominated succession (Figs. 4; 5). In the Montes de Castejón, some 20km to the east of Plana de la Negra-Sancho Abarca area, the T5/T6 boundary is marked by a change from a heterolithic succession dominated by ochre and red mudstones and minor overlying gypsum to a prominent limestone-dominated sequence (Arenas, 1993).
Further southeast, in the central sector of the basin, this boundary is seen as a sharp transition from evaporitic to carbonate deposits (Pérez, 1989) and, towards the northern and eastern sectors, it is found within a carbonate succession (Arenas, 1993; Arenas and Pardo, 2000).

\section{Correlation with adjacent areas}

The two studied stratigraphic sections were correlated with laterally-equivalent deposits exposed in three previously described sections, using the T5/T6 boundary surface as a regional marker, together with the vertical sedimentary trends (Fig. 6). The sections are: Pico del Fraile (Larrasoaña et al., 2006) and Loma Negra (Martínez-García et al., 2014) in the Bardenas Reales area, and Castillo de Sora (Pérez-Rivarés, 2016) in the Montes de Castejón area (see Fig. 1B for location of all sections). These sections show a similar arrangement of facies as compared to the studied sections herein, and provide biostratigraphic and magnetostratigraphic data, which then permit accurate dating of the two studied sections.

A magnetostratigraphic correlation has been performed between: i) section Pico del Fraile (Larrasoaña et al., 2006), approximately $3 \mathrm{~km}$ southwest of the studied area; ii) the uppermost $85 \mathrm{~m}$ of section Sancho Abarca, as measured by Larrasoaña et al. (2006), and iii) the Castillo de Sora section, as measured by Pérez-Rivarés (2016),

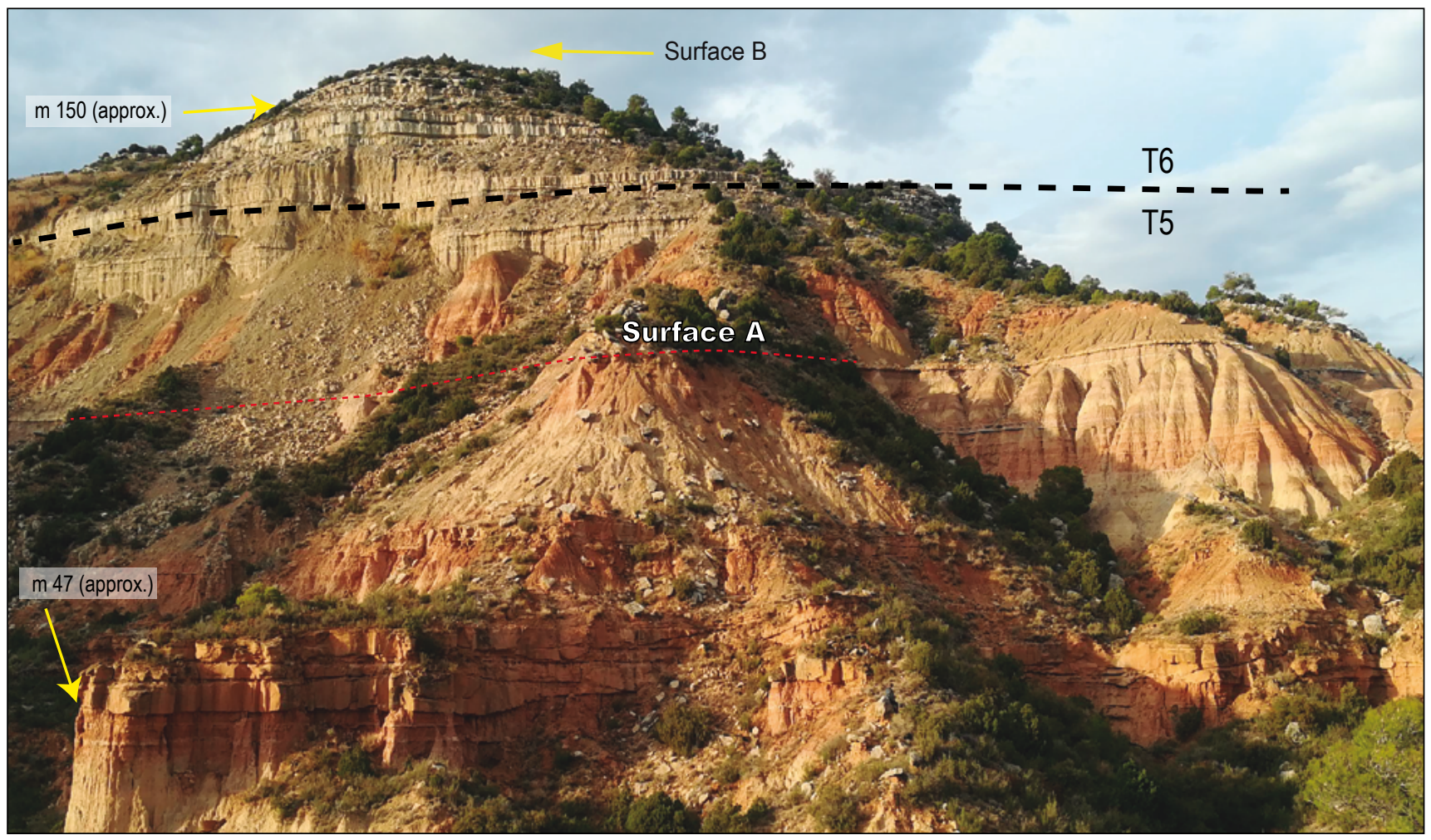

FIGURE 5. General view of the Corretroncos section, looking north. The main lithological features can be identified by comparison with Figure 3 . The position of the T5/T6 boundary, surfaces A and B, and other reference data are highlighted. 


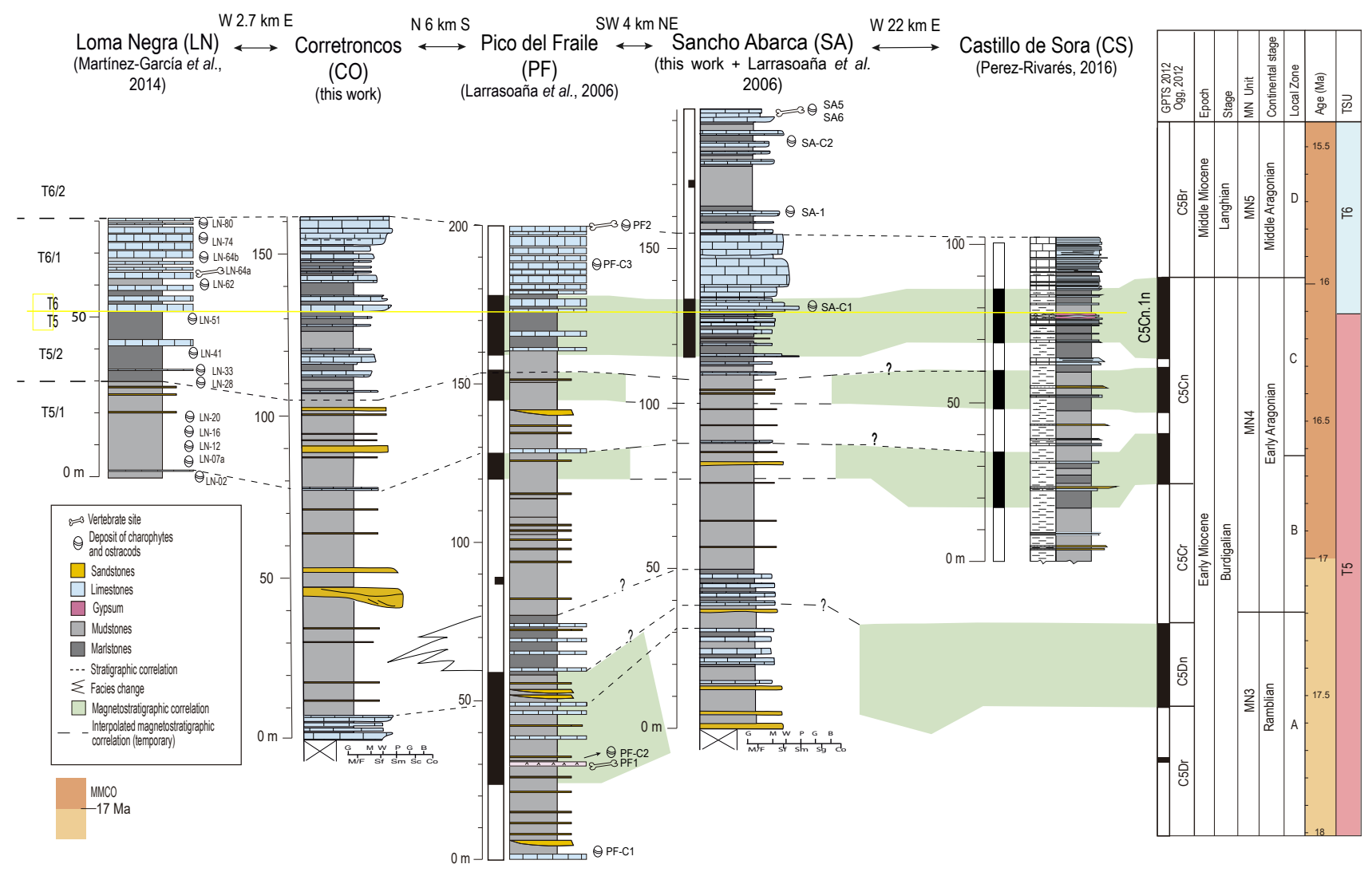

FIGURE 6. Correlation panel for the two sections measured in this study Sancho Abarca and Corretroncos) and other nearby measured sections described by previous authors (Loma Negra, Pico del Fraile and Castillo de Sora). Main datum is taken as the T5/T6 boundary, with stages T5 1/2 and T6 1/2 also shown. The chronological scheme is that used by Pérez-Rivarés (2016) and Suarez-Hernando (2017). Symbols at the base of sections: M: Mudstone; W: Wackestone; P: Packestone; G: Grainstone; F: Fines (claystone and siltstone); M: Marls; Sf, Sm and Sc: fine, medium and coarse Sandstone; Co: Conglomerate.

approximately $22 \mathrm{~km}$ east of the studied area (Fig. 1B). The complete magnetostratigraphic sequence has been correlated by the authors with the Geomagnetic Polarity Time Scale of Ogss (2012).

The boundary T5/T6, main reference surface for correlation (Fig. 6), was dated by Pérez-Rivarés (2016) through magnetostratigraphy in several sections of the central sector of the Ebro Basin. In the Castillo de Sora section the boundary was set at $16,099 \mathrm{Ma}$. This author, by using the Larrasoaña et al. (2006) magnetostratigraphy from section Pico del Fraile, set the boundary T5/T6 at 16,062Ma in Pico del Fraile. In both cases, corresponding to chron C5Cn.1n (Burdigalian, early Miocene).

The Loma Negra section, approximately $2.7 \mathrm{~km}$ northwest of the Corretroncos section, has been integrated in the correlation diagram(Figs. 1B; 6) using the biostratigraphic data provided by Martínez-García et al. (2014), and considering the boundary T5/T6. In micromammal fossil sites in close areas (LN-64a, PF2, SA5 and SA6; summarized in SuarezHernando, 2017), the presence of Vasseuromys cristinae (Ruiz-Sánchez et al., 2013; Suarez-Hernando, 2017) has been attributed to the middle Aragonian, in local zone D and European land Mammal unit MN5 (Daams and Freudenthel, 1988; Van der Meulen et al., 2012). Located at the base of section Pico del Fraile, fossil site PF1 was attributed by Larrasoaña et al. (2006) and Ruiz-Sánchez (2012) to the local zone A. This fossil site contains Simplomys simplicidens, Vasseuromys rambliensis, Eomyidae indet., Ochotonidae indet. and Soricidae indet. According to Suarez-Hernando (2017), the absence of cricetids and the abundance of glirids justify the attribution of PF1 to biozone A, in the Ramblian, which is correlatable with MN3.

Correlation with the available magnetostratigraphic data and published micromammal ages (as exposed above) allows dating of the studied deposits as Ramblian (MN3) to middle Aragonian (MN4), i.e. from C5Dr to C5Br (Fig. 6).

\section{SEDIMENTOLOGY}

Up to seventeen sedimentary facies have been differentiated according to lithology, textural features, allochem components and sedimentary structures. 

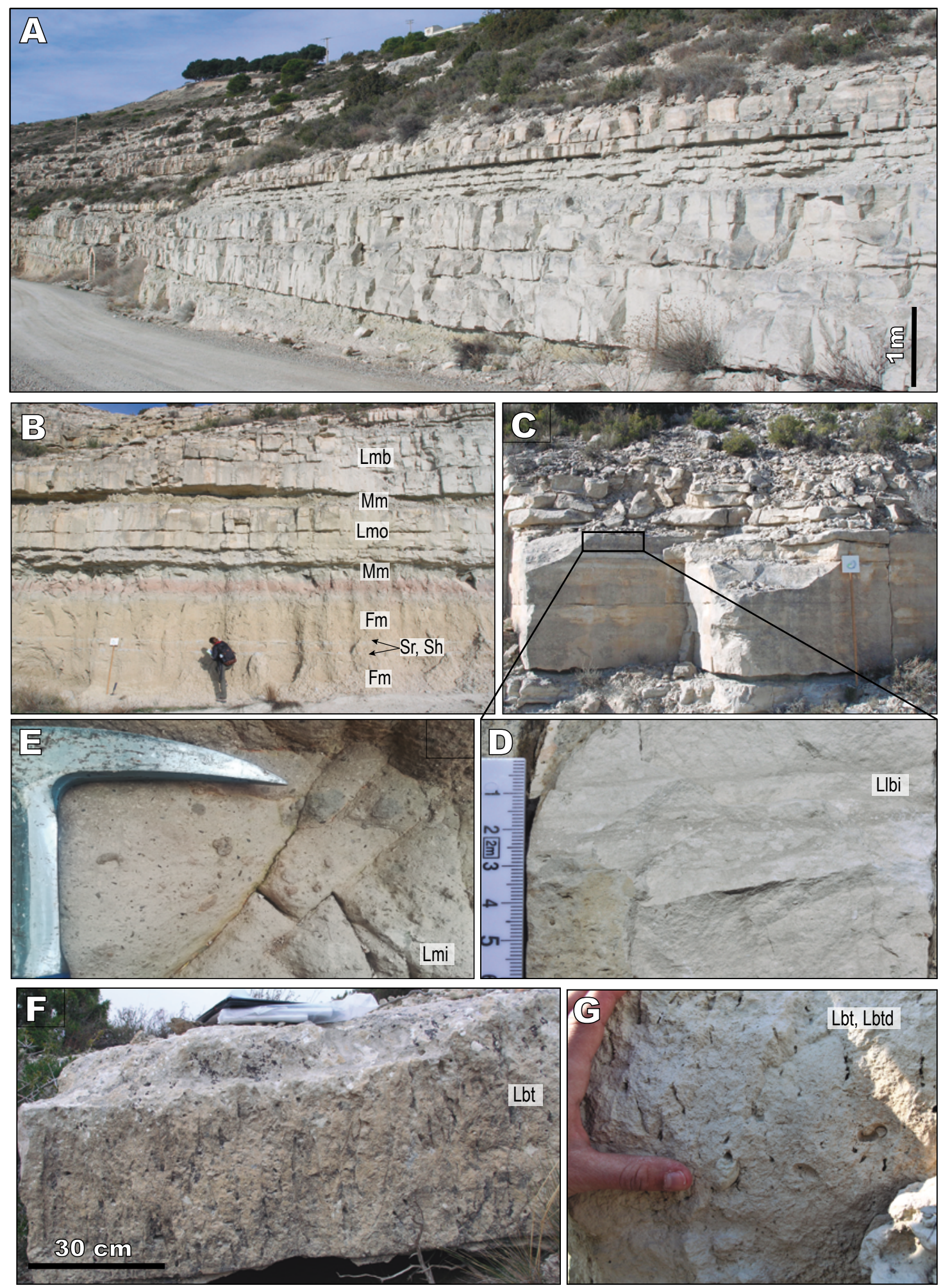

FIGURE 7. Field views of several lithofacies and facies (Table | for symbols). A) Tabular limestone and minor marl strata of lithofacies 4 in Sancho Abarca section (unit T6). Note the varied thickness and extensive lateral continuity of strata. B) Yellowish and pinkish fine detrital deposits (mudstones, facies Fm, and sandstones, facies Sr, Sh) passing upward to minor marl strata (facies Mm) and light grey and cream limestone (facies Lmo and Lmb). C) Tabular limestone strata in Sancho Abarca section. The thickest bed consists of laminated limestones (facies LIbi). D) Detail of C) showing laminae consisting of mudstone and bioclast and intraclast wackestone-packstone. E) Dark and light gray, angular and subrounded, poorly sorted intraclasts, along with smaller shell fragments of bivalves, typical of massive intraclastic limestones (facies Lmi), which also contain small quarz grains. F) Bioclastic limestone with empty subvertical traces that correspond to root bioturbation (Lbt). G) Bioclastic limestone with root bioturbation (facies Lbt) and desiccation craks (Lbtd). Note the presence of gastropods and small cracks. 

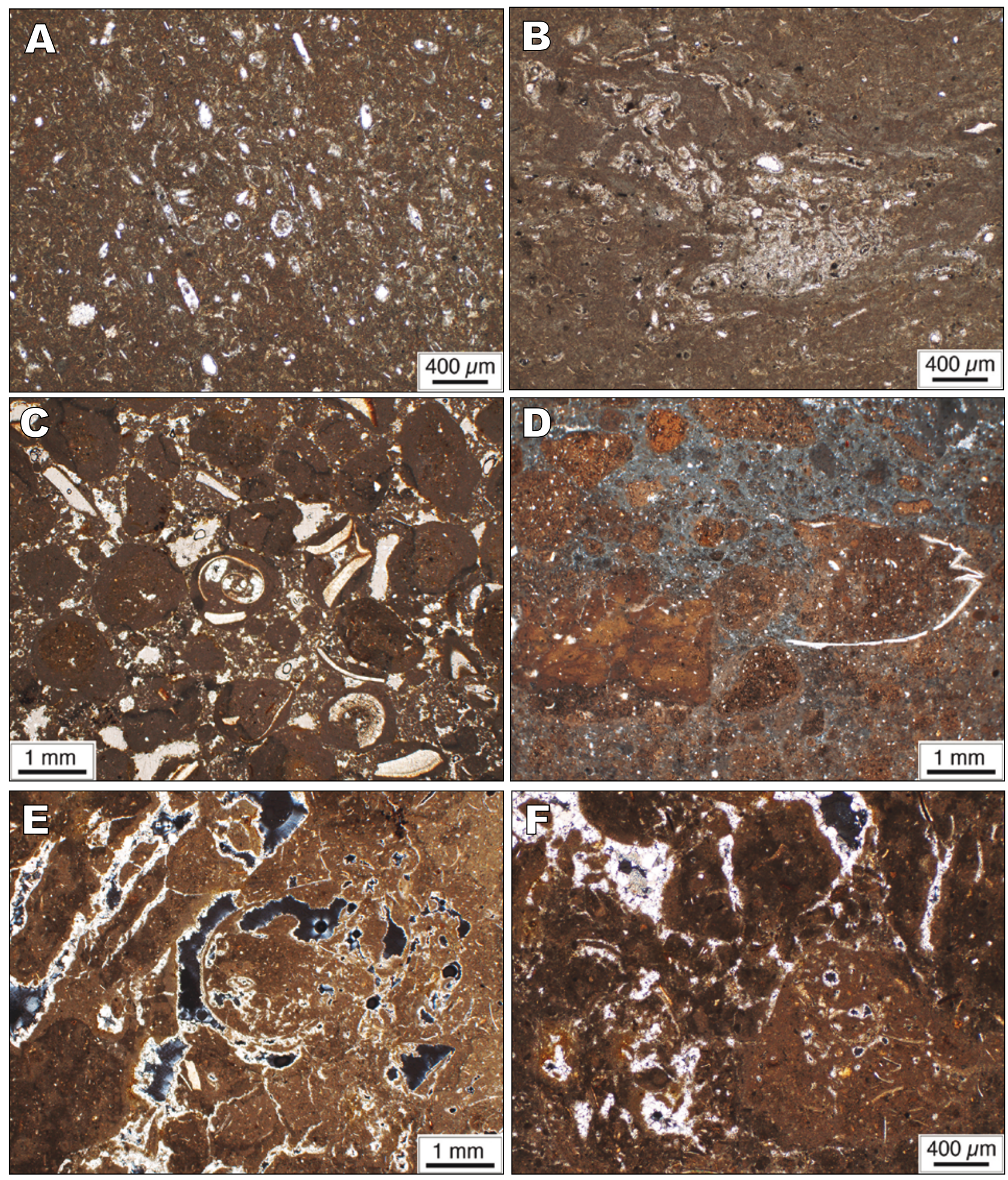

FIGURE 8. Representative microfacies (photomicrographs under plane polarized light). A) Wackestone consisting of charophyte gyrogonites and thali (facies Lmc.) B) Accumulation of charophyte gyrogonites (partly preserved in calcite spar) in irregular zones (facies Lmc). C) Intraclass limestones with intraclasts derived of intraclastic and bioclastic limestones (producing polyphasic intraclasts) (facies Lmip). D) Unsorted, poymict intraclasts, minor bivalve shell fragments and disperse quartz grains (facies Lmi). E) Bioclastic limestone with circumgranular cracks that are filled with calcitic cement, denoting formation of nodules by dessication and pedogenesis (facies Lbtd). F) Bioclastic limestone with circumgranular cracks, nodules and breccias, and spar calcite cement, possible "pseudomicrokarst" as described by Plaziat and Freytet (1978), (facies Lbtd). 

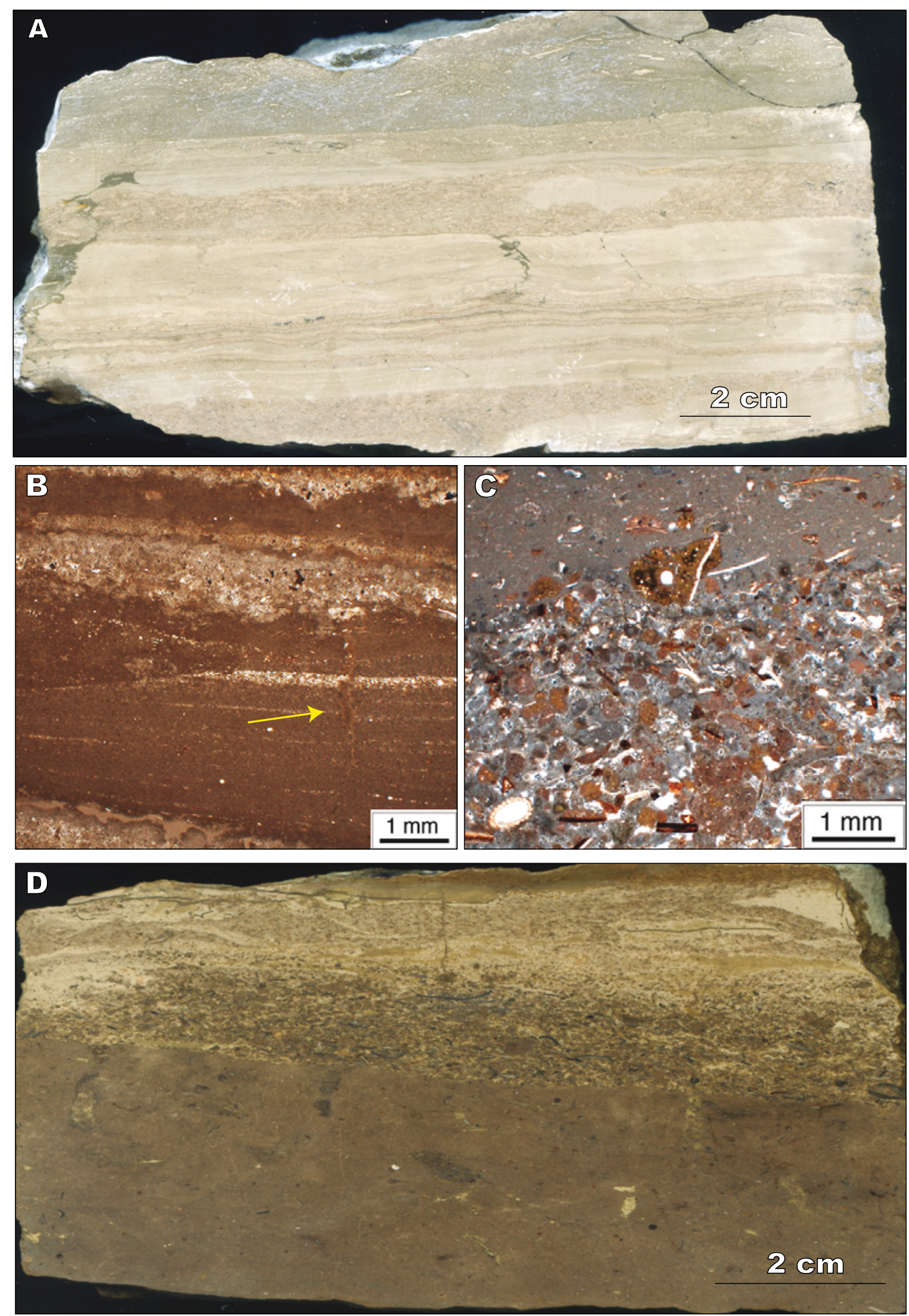

FIGURE 9. Features of laminated limestones on polished rock slabs ( $A$ and D) and photomicrographs from thin sections (B and C). A) Horizontal lamination showing varied composition (facies Llsc). B) Photomicrograph of sample in Figure 7A), showing the sharp contact between carbonate and siliciclastic laminae, cross lamination and a vertical bioturbation trace (arrowed). C) Gradual graded transition from intraclast-rich and bioclastrich to micrite-rich laminae, with decreasing size of bioclasts and intraclasts upward in the wackstone-packstone lamina (facies LIbi). D) Bands and irregular laminae of facies Llio, consisting of discontinuous and disrupted mudstone and wackestone-packstone, locally grainstone laminae, formed of intraclasts and ooids (facies Llio). 
Carbonate facies have been named according to texture and the most abundant allochem components and/or the most relevant sedimentary features. Clastic and mixed and facies take their names from the sedimentary structures they exhibit. Table I (see appendix I) summarizes the principal characteristics, abundance and sedimentological interpretation of each facies. The table also provides references to similar facies described and interpreted in the sedimentological literature.

\section{Northern sector}

Carbonates in the Corretroncos section are dominated by massive packstones containing intraclasts, peloids and bioclasts and massive wackestones-packstones containing intraclasts and bioclasts (facies Lmip and Lmi); these bioclastic limestones may present evidence of bioturbation (facies Lbt), as well as desiccation cracks (Lbtd) (Figs. 7F, G; 8C, D, E, F). Also common are massive bioclast wackestones s.l. (facies Lmb; Fig. 7B) and massive marls (facies Mm; Fig. 7B). Rather rare are rudstone-wackestones containing ostracods and charophytes and laminated marls (facies Lmo and Ml; Figs. 7B). Laminated limestones, comprising alternating laminae formed of mudstone and intraclast and ooid wackestone-packstones and ocassionally grainstones, occur only in this northern part of the studied area (facies Llio; Fig. 9D).

Massive sandstone bodies (facies Sm; Figs. 10C, D; $11 \mathrm{~B}, \mathrm{C})$ alternate with massive and bioturbated mudstones,
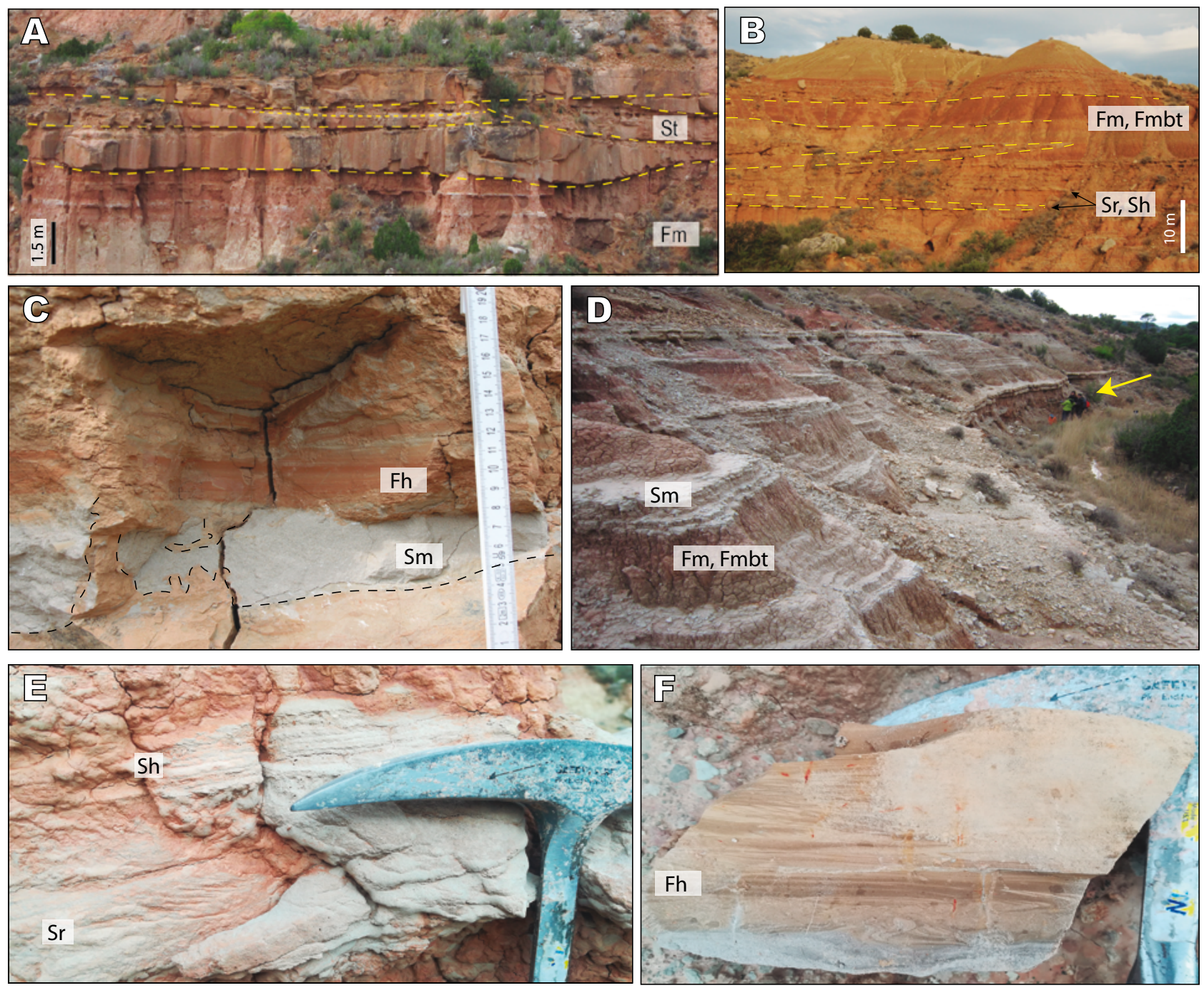

FIGURE 10. Field images of siliciclastic facies in the Corretroncos section. A) Massive mudstones $(\mathrm{Fm})$ at the base overlain by tabular and channel sandstones (locally showing cross stratification, facies St). At the base, massive mudstones (Fm). B) Thick mudstone deposits (facies Fm and Fmbt) with sandstone intercalations (facies Sh, Sr) thinning laterally (pinch-out) to the right. C) Erosional contact between laminated mudstones (facies Fh) and massive sandstones (facies Sm). D) Alternating reddish mudstone (facies Fm and Fmbt) and light greyish tabular sandstone bodies (facies Sm), with great lateral continuity. Arrow points to people for scale. E) Detail of cross and horizontal lamination in medium grained sandstones (facies Sh and Sr). F) Detail of facies Fh, with convoluted laminae at the base. 

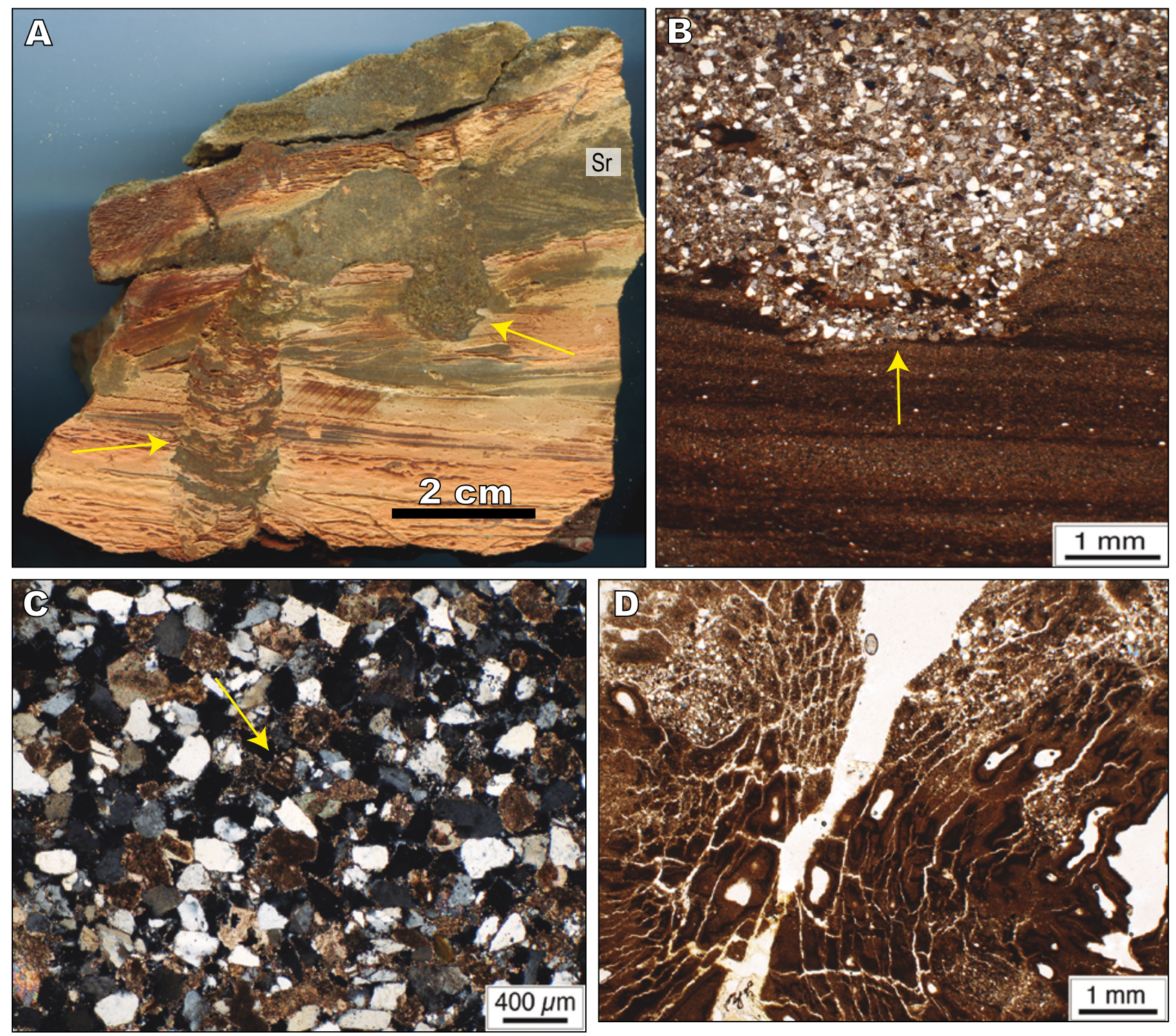

FIGURE 11. Features of siliciclastic facies on polished rock slabs (A) and photomicrographs from thin sections (B, C and D). A) Orange laminated mudstone, including grey siltstone-fine sandstone layers with cross stratification (Sr). Note vertical bioturbation traces (arrowed; facies Fhbt). B) Photomicrograph from deposits shown in Figure 8D; the laminated mustones (Fh) at the base are sharply eroded by "micro-scours" filled with massive sanstones (base is arrowed; Sm). C) Quartz and carbonate grains of a sublithoarenite, including a reworked foraminifer shell (arrowed). D) Mudstones with root traces that have mixed up the original sediment (facies Fmbt)

which are among the most common detrital facies (facies Fm. y Fmbt; Figs. 10A, B, D; 11D). Following in abundance, there are sandstone bodies with horizontal and cross lamination (facies Sh, Sr; Fig. 10B, E), sandstones with trough cross-stratification (facies St; Fig. 10B) and mudstones with horizontal lamination and bioturbation (facies Fh y Fhbt; Figs. 10C, F; 11A, B).

\section{Southern sector}

In the Sancho Abarca section carbonate facies are dominated by massive packstones containing intraclasts, peloids and bioclasts, with less abundant wackestone-packstones consisting of intraclasts and bioclasts (facies Lmip y Lmi; Fig. 8C, D) and bioturbated limestones (i.e. facies Lbt y Lbtd; Figs. 7F, G; 8E, F) compared to the northern part. In contrast, charophyte wackestone-packstones (facies Lmc; Fig. $8 \mathrm{~A}, \mathrm{~B})$, laminated limestones formed of alternating carbonate and siliciclastic laminae, and laminated limestones formed of mudstone laminae and bioclast and intraclast wackestone-packstones laminae (facies Llcs y Llbi; Fig. 9A, B, C) are unique to the southern outcrops. 


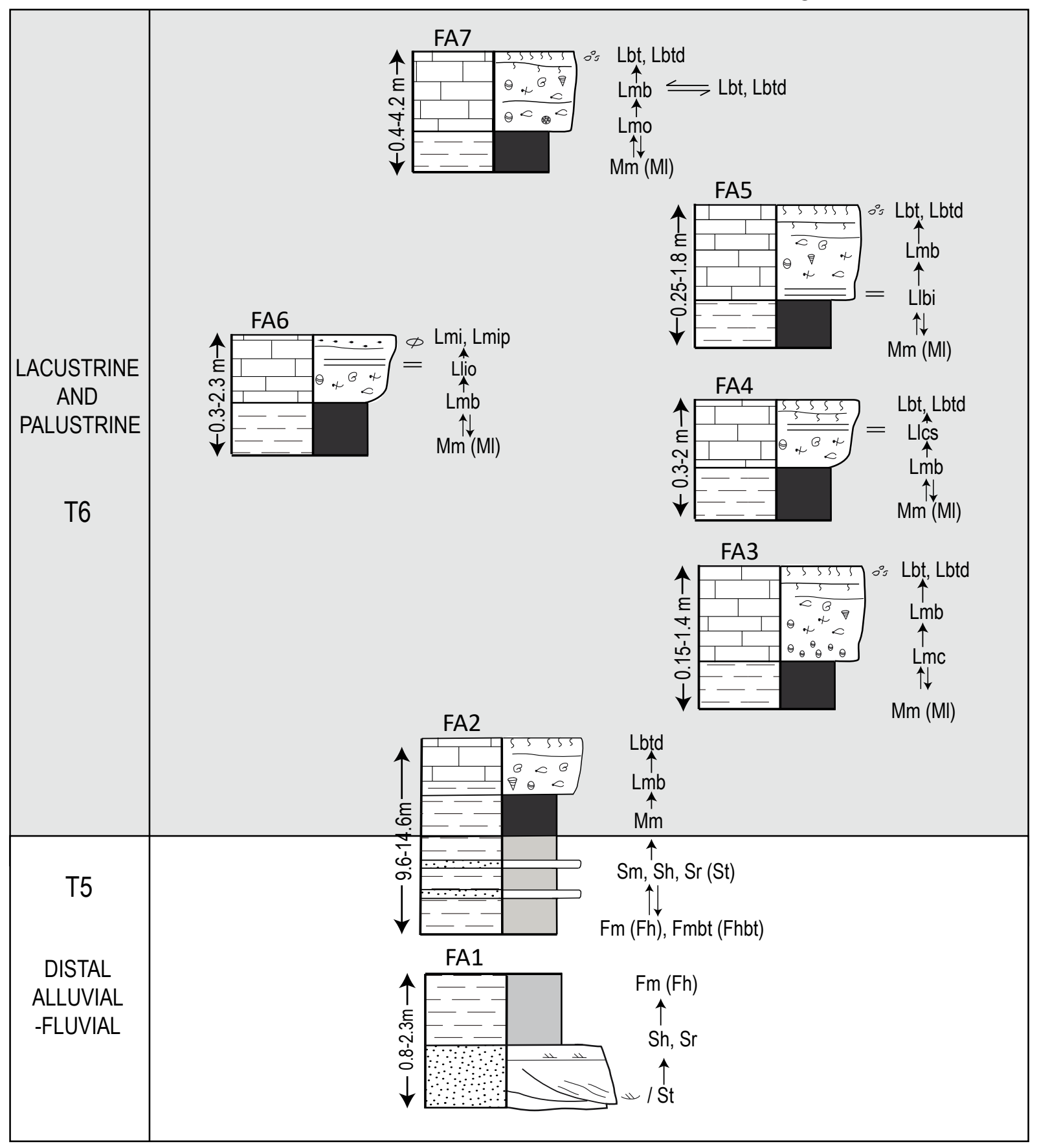

\begin{tabular}{|c|c|c|c|c|c|c|}
\hline \begin{tabular}{|l|l|l|l|} 
& & & \\
\end{tabular} & Limestones & $\theta$ Charophytes & $=$ & Horizontal & $\varnothing$ Intraclasts & $\uparrow$ Vertical passage \\
\hline & Marls and & $\propto$ Ostracods & & lamination & $\circ$ Brecciation & Erosional base \\
\hline & marlstones & * Shell fragments & עد & Trough & ( ) Occasional facies & $\downarrow \uparrow$ Alternating facies \\
\hline & Sandstones & 쿠 Gastropods & & Trough cross- & $\leftrightharpoons$ Lateral passage & $\mathrm{Al}$ \\
\hline$E$ & Mudstones & $\begin{array}{l}\text { S Root bioturba- } \\
\text { tion }\end{array}$ & & stratification & & \\
\hline
\end{tabular}

FIGURE 12. Typical facies associations (i.e. sequences) representing the three sedimentary environments (fluvial-distal alluvial, lacustrine and palustrine) recorded in the studied succession. 
The following clastic alluvial facies are present in the south: massive mudstones (facies Fm..; Figs. 10A, $\mathrm{B}, \mathrm{D} ; 11 \mathrm{D})$ and a range of sandstones. These are mainly horizontally and cross-laminated, and more rarely trough cross-stratified (facies Sh, Sr and St; Fig. 10A, E) and massive (facies Sm; Figs. 10C, D; 11B, C).

\section{Facies associations}

The sedimentary facies described in Table I are stacked in simple, centimetre- to metre-thick sequences, named Facies Associations (FA). These FA represent the superposition of deposits developed in laterally related subenvironments, and its vertical evolution is interpreted to reflect cycles of water level variation, channel fill processes, avulsion, etc., corresponding with progradation/ retrogradation of the alluvial-fluvial system and expansion/ contraction of the coeval lacustrine-palustrine system.

Seven FA have been identified (Fig. 12). FA3 to 7 and the upper half of 2 correspond to a lacustrine environment with palustrine fringes. FA1 and the lower half of FA2 represent distal fluvial-alluvial deposition. FA1, 2 and 7 occur in both the northern and southern sectors, FA6 is only present in the northern sector, while FA3, 4 and 5 are present only in the south. FA3 to 7 and the upper half of 2 reflect shallowingupward processes and in some cases culminating with subaerial exposure at the top of the sequence.

FA1 reflects sedimentation in distal fluvial areas. The lower sandstone bodies represent incision and then filling of low sinuosity and high-energy channels, with development of small to medium-scale sandy dunes that would generate trough cross-stratification (St; Table I). Waning current produced deposition of fine sand with horizontal and/or cross lamination (Sh, Sr). Channel filling was followed by channel abandonment and migration, leading to deposition of fine siliciclastics representing the floodplain. Occasional plant colonization and oxidation during subaerial exposure, and sedimentation interruptions gave rise to facies Fm., Fmbt, Fh and Fhbt (Figs. 10A, B, D, E; 11A, B). This type of FA is common in middle to distal parts of many fluvial systems (Miall, 1996; Porter and Gallois, 2008).

FA2 represents distal alluvial deposition followed by lacustrine and palustrine deposition, thus recording expansion of the lake area through time. The lower half reflects sedimentation in distal alluvial plains, with siliciclastic mud and sand sedimentation, and affected by low energy tractive unconfined flows, likely corresponding to lateral and terminal splays (Nichols and Fisher, 2007). Deposition from rapid deceleration of these flows would produce thin interbedded massive tabular sand bodies (Brierley, 1996; Fisher et al., 2007; Paredes et al., 2007). Over these siliciclastic mudstones, marls represent first lake expansion, with increasing water level (Mm), then lowering lake level allowing lime mud deposition with bioclasts (Lmb). Commonly, the tops of these limestone strata are affected by root bioturbation and desiccation cracks (Lbtg), which are typical features of palustrine conditions and subaerial exposure (e.g. Alonso-Zarza, 2003; Freytet and Plaziat, 1982).

FA3 is characterized by the upward transition from marls into lime mud facies with abundant charophyte, gyrogonites and thalli. These facies (Lmc) indicate stabilization of lake level to allow the development of extensive charophyte meadows in the photic zone and in still conditions ( $c f$. Sáez et al., 2007a; Soulié-Märsche et al., 2010). The upper part of this facies sequence represents shallow areas vegetated by hydrophilous plants and affected by lake level variations, causing bioturbation of the lime mud by roots, nodulization, desiccation cracks (facies Lbt and Lbtg; Scott and Smitt, 2015) and, in some cases, pseudomicrokarst and brecciation (Alonso-Zarza et al., 1992; Plaziat and Freytet, 1978).

FA4 formed in a lacustrine environment that shared characteristics with that represented by the lower part of FA6. In this case, the shallow areas would record deposition during calm or low energy periods, alternating with high energy events, e.g. by currents that rework and transport bioclasts (Clausing and Boy, 2000; Glenn and Kelts, 1991). Facies Llcs would form from fine siliciclastic sediment transported by currents originated from episodic fluvial inputs (Table I). These laminated limestones are occasionally bioturbated by benthonic organisms (Fig. 9B). This biogenic structure denotes the probably shallow conditions (Scott and Smith, 2015), with occurrence of episodic current activity. The upper part of FA4 represents shallowing conditions as interpreted in FA3.

FA5 begins with massive, occasionally laminated, marls (facies $\mathrm{Mm}$ y Ml) that would form in calm offshore zones, in which the absence of currents and bioturbation would allow primary lamination to be preserved ( $c f$. Gierlowski-Kordesch, 2010). The upward passage from marls to laminated limestones (facies Llbi) indicates the occurrence of currents that transported intraclasts and bioclasts from the shallow areas. The decreasing in the size of bioclasts and the upward increase of micrite content within the laminae suggest deposition from discrete events associated with density currents (Fig. 9C) (Sáez et al., 2007b). Shallow lacustrine areas would be loci for prolific development of ostracods and charophytes, and minor gastropods and bivalves (facies Lmb), leading to the formation of bioclastic limestones, e.g. as described by Platt (1989, 1995), Platt and Pujalte (1994) and Quijada (2014) in the early Cretaceous lacustrine systems of the western and eastern Cameros basins, in north Spain. The 


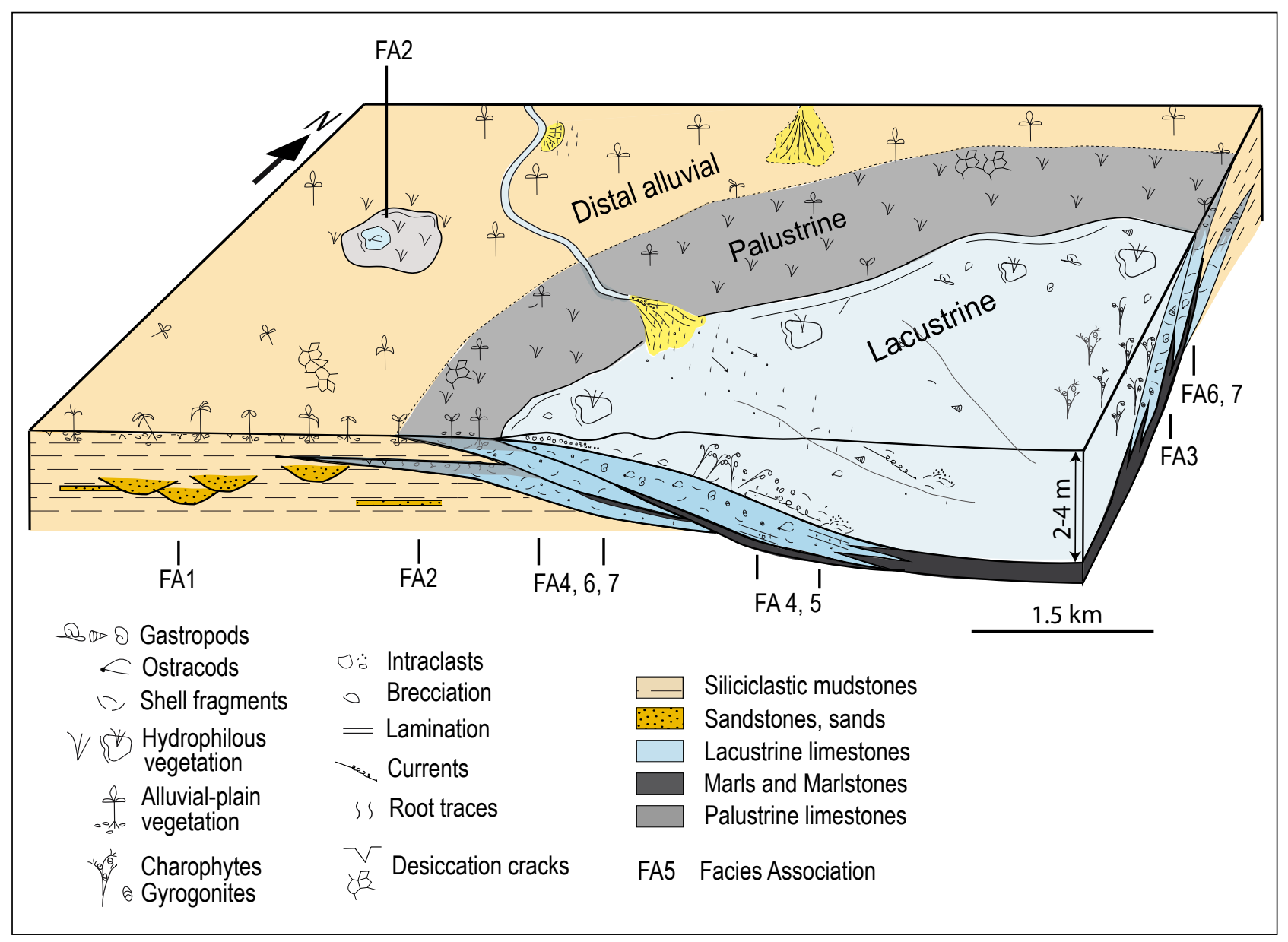

FIGURE 13. Sedimentary facies model proposed for the distal alluvial-fluvial, palustrine and lacustrine deposition in the study area.

upper part of FA5 exhibits characteristics to the top of FA3, with indications of emergence and plant colonization in palustrine conditions.

FA6 has been defined in the northern sector of the study area. It has similarities with FA7 in the lower part, with marls (facies $\mathrm{Mm}$ and $\mathrm{Ml}$ ) and bioclastic limestones (Lmb; Table I), which formed in calm offshore lake zones. Laminated limestones containing intraclasts and ooids (Llio; Table I) indicate water level agitation by currents (e.g. storms and related inflows, and wind-induced currents during fair weather) that would generate intraclasts and favor the formation of ooids, depositing them in close offshore areas (cf. Quijada et al., 2013). In marginal areas more directly affected by inflows/currents, deposition of bioclasts, intraclasts and small quartz grains would produce wackestone-packstones (Lmi; Table I).

FA7 represents shallowing from lacustrine to palustrine conditions. Marls reflect offshore settling of fine siliciclastic sediments and lime mud from within the water column, following water inputs. The overlying limestones with abundant ostracods, charophyte gyrogonites and thalli, and fragments of gastropods and bivalves (facies Lmo and Lmb; Table I) indicate deposition in an open lacustrine area (cf. Platt and Wright, 1991; Vázquez-Urbez et al., 2013). In marginal and/or shallow zones, colonization of hydrophilous plants and episodic desiccation and flooding would cause nodulization and the formation of desiccation cracks (Figs. 7G; 8E, F), e.g. as described in the Bembridge Limestone (Late Eocene) in southern England (Armenteros and Daley, 1998) and in the modern day Florida Everglades (Platt and Wright, 1992).

\section{Sedimentary facies model}

A sedimentary facies model has been constructed for the study area taking into account the facies and facies associations and their spatial distributions (Fig. 13). Particular attention has been paid to studies investigating the depositional environment colonized by charophytes (González-Pardos, 2012) and ostracods (Martínez-García et al., 2014) in the Miocene of the Ebro Basin, in areas close to this study. 
Charophytes are good indicators of environmental conditions in lakes (e.g. water composition, depth, light and dynamics). The chemical composition of water is the most important parameter constraining charophyte development; water chemistry and $\mathrm{pH}$ largely determine the distribution of different species. Charophyptes thrive in alkaline and oligotrophic lakes and disappear where phosphorus and nitrogen concentrations are high (Martín-Closas and Diéguez, 1998).

The most common genuses in the studied sections are Chara and Lychnothamnus (González-Pardos, 2012). At present, Lychnothamnus barbatus is found at depths of 2 to $4 \mathrm{~m}$ in cool-water, low energy lakes (Soulié-Märche et al., 2010), as in the cases of some modern mid latitude lakes (e.g. Zürich Lake, Kelts and Hsü, 1978). These characteristics can be attributed to the Miocene lake in the studied area.

Ostracods are the second most abundant organisms in the studied sections. In nearby areas the basal sections, show an abundance of Paralimnocythere sp. in marls and limestones, suggesting deposition in shallow stagnant ponds in distal alluvial environments, with warm and oligohaline fresh water (Martínez-García et al., 2014). The occurrence of sandstone layers containing Cyclocypris levis suggests relatively higher energy (Martínez-García et al., 2014). The abundance of Pseudocandona parallela in marls and limestones of the uppermost parts of sections in adjacent areas, allowed this authors to infer a stable lake with a higher water column and cooler freshwater to mesohaline water.

The depositional environment is interpreted as a lowgradient and shallow lacustrine system, probably between 2 to $4 \mathrm{~m}$ in depth (Fig. 13), and with slighly cool water. The studied area was part of a larger lacustrine system with similar physiographic characteristics that extended tens of kilometres through the central Ebro Basin (cf. Arenas and Pardo, 1999). Carbonate deposition would take place in the littoral and sublittoral zones and marls would be deposited offshore. Charophyte limestone facies may reflect deposition at greater depth than gastropod and bivalve limestone facies. Periodic brecciation and reworking by density currents are thought to reflect storm and flood events transporting siliciclastics and/or intraclast and ooids offshore.

The lacustrine environments would be surrounded by discontinuous palustrine fringes with abundant hydrophilous vegetation, associated with the lake margin and with distal alluvial areas. Migration of these fringes would be directly related to changes in lake water level, with varying flooding and emergence, reaching their maximum expansion when the lake level was low. In this context with intermitent subaerial conditions, pedogenic modification would take place. Similar interpretations have been put forward for many palustrine limestone sequences in the Mesozoic and Cenozoic of Europe and North America (Alonso-Zarza, 2003; Armenteros, 1986; Armenteros
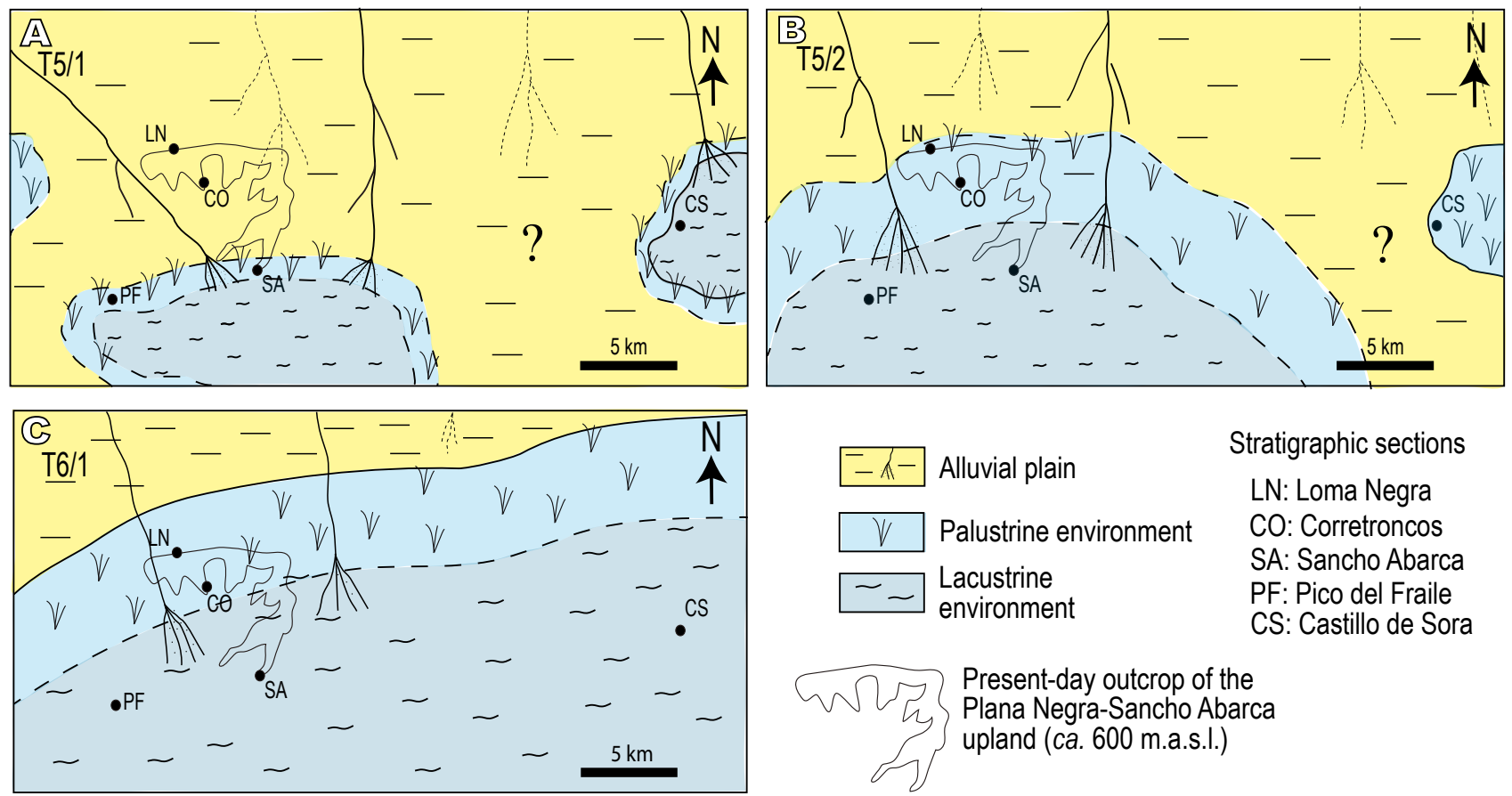

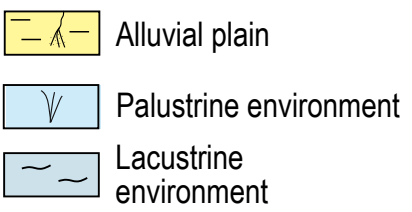

Stratigraphic sections

LN: Loma Negra

CO: Corretroncos

SA: Sancho Abarca

PF: Pico del Fraile

CS: Castillo de Sora

FIGURE 14. Evolution of the studied sedimentary record through time (only T5/1, T5/2 and T6/1 are shown, given the small outcrop of T6/2). A) T5/1 (middle-late Burdigalian), B) T5/2 (late Burdigalian) and C) T6/1 (latest Burdigalian-Langhian). Explanation in the text. 
and Daley, 1998; Gierlowski-Kordesch, 2010; Platt, 1989, 1995; Wright, 1990; among others).

Palaeocurrent analysis in unit T5 suggests water and sediment inputs from a fluvial system from the north (Pyrenean Range; see Fig. 1), i.e. the Luna fluvial system. The distal part of this basin marginal distributary system is interpreted to have been a wide muddy floodplain intersected by rare mostly low-sinuosity channels, with small and shallow ephemeral ponds, where freshwater to oligohaline conditions allowed deposition of the ostracod limestone facies (e.g. Paralimnocythere sp.). These facies would be subject to desiccation and pedogenesis within palustrine zones which were periodically exposed as well.

A similar lacustrine-palustrine facies model was proposed for the Lower Cretaceous of the Serranía de Cuenca, Spain (Gierlowki-Kordesch et al., 1991) and for the freshwater lakes of the lower and middle Miocene of the central sector of the Ebro Basin (Arenas and Pardo, 1999).

\section{DISCUSSION}

Concerning the boundary T5/T6 established herein through stratigraphic criteria and dated by correlation with other nearby areas having magnetostratiphic studies, the age proposed for this boundary in the Sancho Abarca-Plana de la Negra area $(16.05$ to $16.06 \mathrm{Ma})$ is consistent with the small diachrony ( $c$ a 30ka) of this boundary throughout the Ebro Basin centre (Pérez-Rivarés et al., 2018).

Sedimentological analysis of the studied sections and stratigraphic correlation with three nearby sections (Fig. 6) have allowed reconstruction of the palaeogeographic evolution for units T5 and T6 (cf. Muñoz et al., 2002; Pardo et al., 2004). This evolution prompts a discussion on the allogenic factors that controlled the sedimentary evolution through space and time.

\section{Palaeogeographic evolution}

The palaeogeographic evolution of the study area can be described through four successive stages (Figs. 6;14). Unit T5 in the study area is formed by several fining-upward macrosequences and, though incomplete (as the base of the unit is not present in this area), the overall evolution is also fining-upward in the central part of the basin (Arenas, 1993). The interval of Unit T6 recorded in Sancho Abarca in turn describes a trend from carbonate-rich to marly-rich facies.

In unit T5, the alluvial deposits are more abundant in the northern portion of the studied area (CO section). To the east, in the Montes de Castejón area (section Castillo de Sora), the top of unit T5 is formed by evaporitic deposits (i.e. nodular gypsum levels within marls and limestones), which were deposited in a saline mud flat context (Arenas and Pardo, 1999) These evaporitic deposits overlie distal alluvial and palustrine deposits. To the west, in the Sancho Abarca and Pico del Fraile sections, shallow lacustrine carbonate sedimentation dominated at the end of deposition of unit T5. Northwards, these deposits grade laterally into distal alluvial deposits with root bioturbation traces (e.g. in the Corretroncos section). In contrast, unit T6 deposition represents, first, the expansion of lacustrine and palustrine conditions, then shallowing, with return of fine-grained clastics from the fluvial system.

Stage $1(\mathrm{~T} 5 / 1)$ is represented by the lower to middle portion in each of the sections (Fig. 6). Floodplain mudstones, with sandstones representing sheet-like flooding and low-sinuosity ephemeral channels made up most of the upper portion of this stage, with rare lacustrine deposition (marls and limestones). Lacustrine deposition is, however, more common in the lower portion of sections $\mathrm{CO}, \mathrm{PF}$ and SA, represented by intervals of limestones and marls (e.g. between metres 20 and 30 in the SA section; Fig. 6). Overall, the upper part of this stage corresponds to an extensive alluvial floodplain in which, occasionally, small ponded areas surrounded by palustrine fringes developed, as represented in Figure 14A. The greater thickness of the mudstone deposits in the north and the paleocurrent directions measured at Correctroncos section, both suggest sediment provenance from the north. This is consistent with paleocurrents oriented from the north in the distal areas of the Luna fluvial system further to the north (PérezRivarés et al., 2018), where sediment supply was derived from the Pyrenean margin (see Figs. 1; 2). Paleocurrents from the northwest, however, would suggest overspilling of channels flowing from the north (i.e. overbank deposits; Fig. 10B, D).

Stage 2 spans the upper $20 \mathrm{~m}$ of unit T5 (T5/2) and records a gradual change from the laterally extensive distal alluvial floodplain to dominant lacustrine carbonate deposits of T6/1 (Fig. 14B). This evolution is interpreted to reflect a progressive expansion of carbonate lacustrine sedimentation in the area of Plana de la Negra-Sancho Abarca, as clastic supply from the Pyrenean fluvial system diminished. Further to the east, in the western part of the Montes de Castejón, e.g. at Castillo de Sora (see Figs. 1B; 6), gypsum facies within marls and limestones occurred at the end of this stage (coindicing with the top of unit T5). These gypsum-rich facies reflect low lake level with evaporite overprint occurring in an area representing a north-south oriented low-relief barrier. This area corresponded to exposed fringes of previous saline carbonate depositional areas in the Montes de Castejón (Arenas et al., 1999), while outer freshwater-carbonate fringes, as formed in the 
Plana de la Negra-Sancho Abarca area, could be affected by desiccation and pedogenetic processes (Arenas and Pardo, 1999). There are not enough data to prove whether the lacustrine area in Plana de la Negra-Sancho Abarca and Montes de Castejón corresponded to a single water body.

T6/1 is formed mainly of limestones in the Loma Negra, Pico del Fraile and Castillo de Sora sections (Fig. 6), Root traces and nodulisation are more abundant in the north, at Loma Negra and Corretroncos sections than in the south, at Pico del Fraile and Sancho Abarca sections (Stage 3, Fig. 14C). This facies distribution suggests an initial deepening and expansion of the lake area followed by shallowing and expansion of palustrine areas at the end of the stage, i.e. the development of a palustrine fringe across the studied area, reflecting a relative decrease of water supply into the lake.

T6/2 comprises fine alluvial clastics which are only present in the south and southeastern portions of the study area (upper part of section SA). The presence of interbedded thin limestone beds suggest the occurrence of small shallow lakes and/or the expansion phases northward of a larger lake on a distal alluvial plain. No palaeocurrent data could be collected from the deposits in this stage. On the basis of mineral composition, crystallochemical parameters of illites and the palaeogeographic evolution, Arenas et al. (1993) and Arenas and Pardo (1999) inferred that the deposition of the lacustrine record of unit T6 in the southeast (e.g. Montes de Castejón and Sierra de Alcubierre; see Fig. 1A for location) was linked to sediment supply from the Pyrenean margin, which most likely was the situation in the study area.

\section{Allogenic factors: tectonics and climate}

The evolution of the Ebro Basin during the Miocene was mainly controlled by compressional tectonic activity at the Pyrenean and Iberian bounding margins (Riba et al., 1983). Tectonics conditioned the topography and extent of the catchment areas, as well as variations in subsidence and sediment supply to the central zones of the basin until the middle Miocene. From early Miocene times onwards, the Iberian Range acted as an almost passive basin boundary, with extensional tectonic activity confined to the southeast of the basin (Muñoz et al., 2002). The vertical evolution and spatial distribution of lacustrine deposits record significant sedimentary changes that are inferred to reflect climatic variations operating at different scales during the Miocene (Arenas and Pardo, 1999; Vázquez-Urbez et al., 2013; Valero et al., 2014).

\section{Tectonic Control}

At the Pyrenean margin, sedimentation of unit T5 proved to be related to tectonic activity of the Gavarnie thrust unit. Dating indicates that sedimentation of units T5 and T6 was contemporaneous with the emplacement of the Garvarnie unit (Fig. 1A), during the latest phases of movement of the Guarga thrust sheet (Arenas et al., 2001; Millán et al., 1995). In this context, around the boundary between units T4 and T5, during the Aquitanian and lower Burdigalian (lower Miocene), extensive progradation of alluvial fans and fluvial systems ocurred associated with uplift at the Pyrenean range. As a result, progradation of two already existing distributary fluvial systems (i.e. the Huesca and Luna systems, which span deposition of units T4 and T5) occurred over large areas of the basin. The Luna fluvial system, which developed in association with the Guarga thrust sheet emplacement, was the main source to the study area (Fig. 1; Arenas et al., 2001).

Unit T5 in the Luna system has a complex sequential evolution (two cycles fining then coarsening upward, without reaching the end of the unit), directy related to the tectonic deformation. However, in the south, the area of Montes de Castejón, unit T5 has an overall fining upward evolution, with a minor coarsening-fining change in the middle of the unit (Arenas, 1993). From these facts, it was suggested that the sedimentary evolution of this unit in the basin centre was mostly controlled by climate, except for the relative coarsening-fining change, which was correlated to Pyrenean uplift (Arenas, 1993). This relative change occurs stratigraphically below the base of the studied sections herein. The small incursions of distal alluvial deposits southward by the end of deposition of unit T5 were rather related to low lake-level stages. Likely this situation was coeval with a general scenario of increase in humidity by the end of unit T5, though modulated by short periods of increase in aridity, and overall decreasing tectonic activity (Arenas, 1993).

The carbonate and siliciclastic deposits in the lower unit (stage 1, T5/1) correspond to phases of alluvial incursion or modest progradation of the Luna fluvial system, probably favoured by a low lake level, rather than caused by a tectonic pulse, as suggested in nearby areas of the basin (Arenas, 1993) (Fig. 14A). In contrast, the uppermost unit T5 (T5/2) appears to record the overall decrease of alluvial inputs onto the basin centre, and the initial expansion of shallow carbonate lakes across the study area, with saline mud flats developed eastward (Fig. 6). During stage 2 (T5/2), evaporite deposits became dominant throughout the basin centre. Therefore, the tectonic activity does not seem to have exerted a great control on this basin area (Pardo et al., 2004).

Stage T6/1 began with a general expansion of the lacustrine system. Basin margins were broadly similar to the present ( $c f$. Fig. 1A). The carbonate lacustrine system extended southward onlapping against the southern basin 
margin formed by the Iberian Range, where deformation ceased or markedly disminished during late BurdigalianLanghian times (Pérez, 1989). There are no known alluvial deposits dated as equivalent to units T6 and T7 in the Pyrenean margin (Arenas, 1993). In the basin centre, the sequential evolution of unit T6 cannot be attributed to tectonic control, but rather to climate conditions. The identification of Milankovitch cyclicity in T6 lacustrine deposits in the Sierra de Alcubierre indicates that sedimentation also reflected climatic fluctuations associated with precession and shorteccentricity cycles (Pérez-Rivarés, 2016).

It is worth noting that the boundary between units T6 and T7 elsewhere in the basin centre is a sharp lithological change, locally with erosional features, indicative of progradation of Pyrenean alluvial systems throughout the basin centre, likely coeval to renewed Pyrenean uplift (Pardo et al., 2004; Vázquez-Urbez et al., 2013). Locally, on the southern Iberian margin, this boundary is an unconformity within proximal alluvial deposits (Fig. 1A; Pérez Rivarés, 2016). However, the evolution of unit T7 can be both reflecting increasing humidity and tectonic uplift (Arenas, 1993).

\section{Climate control}

Climate controls many lacustrine systems, as is the case of the Miocene Ebro basin; however, discrimination between tectonic and climate influence is not easy (Arenas and Pardo, 1999; Carroll and Bohacs, 1999; Meléndez et al., 2009; Tanner, 2000). Within the context of overall decreasing compressive tectonic activity at the central and western-central basin margins, the upward sequence from distal alluvial deposits to lacustrine carbonate sediments recorded by units T5 and T6 in the study area is consistent with a transition to a more humid climate during the deposition of the studied succession. This interpretation is supported by studies of charophytes (González-Pardos, 2012), ostracods (Martínez-García et al., 2014) and micromammals (Larrasoaña et al., 2006; Murelaga, 2000; Murelaga et al., 2002; Ruiz-Sánchez et al., 2013) in the nearby Pico del Fraile and Loma Negra sections (Figs. 6; 15). This climatic evolution is also consistent with sedimentological interpretations and carbon and oxygen stable isotope results obtained from lacustrine carbonates elsewhere in the Ebro Basin by Arenas and Pardo (1999) and VázquezUrbez et al. (2013). Moreover, this climatic evolution has also been detected in other Neogene lacustrine systems of the Iberian Peninsula (Calvo et al., 1993). In the Madrid Basin, for instance, the upper sequence of the Intermediate Unit represents an expansion of the freshwater lacustrine areas interpreted in terms of increasing humidity (Alonso-Zarza and Calvo, 2002), as is the case of unit T6 in the Ebro Basin.

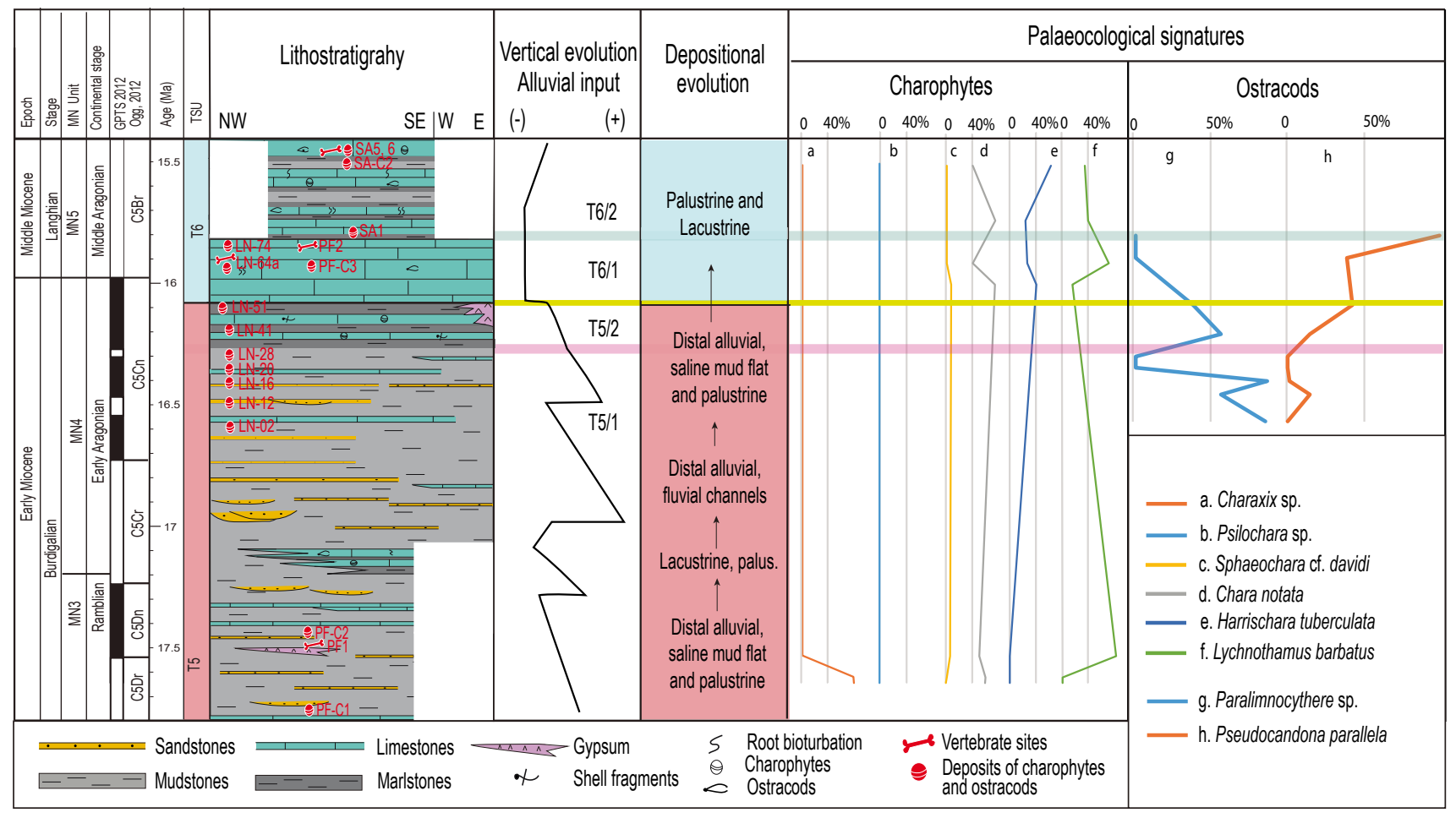

FIGURE 15. Main lithological, palaeontological, environmental and climatic characters for the Plana de la Negra-Sancho Abarca area and northwestern portion of Montes de Castejón through time. The biota curves correspond to proportion in the assemblage of the most abundant taxa of charophytes and ostracods of the fossil sites in the study area. Data from González-Pardos (2012) and Martínez-García et al. (2014). 
The studied interval in the Plana de la Negra-Sancho Abarca area was partly sedimented during the period of warmer conditions referred to as the MMCO (SuarezHernando, 2017). The MMCO is dated from the marine sedimentary record between 17 and $14.5 \mathrm{Ma}$ (Zachos et al., 2001, 2008) and is roughly characterised by an abrupt and persistent increase in temperature and humidity, within a period of progressive cooling throughout the Neogene (Böhme, 2003).

This climatic history is broadly consistent with micromammal, charophyte and ostracod data obtained of lower to middle Miocene strata in the studied area (Fig. 15). Rodent data in the Bardenas Reales area (see Fig. 1 for location) record the establishment of warm conditions at 19Ma (Suarez-Hernando, 2017). Similar support for warming conditions was provided from fossil site PF1, at the base of the Pico del Fraile section, dated at $17.5 \mathrm{Ma}$ (Fig. 6), corresponding with an age below the lower and middle Burdigalian boundary. Younger rodent assemblages in these sections also indicate warm conditions, with a significant increase in humidity (Suarez-Hernando, 2017).

Thus, in the studied continental sediments of the Ebro basin, a warming trend starting $c a .2$ million years earlier than in marine environments, that is, between 20 and $18 \mathrm{Ma}$, has been detected by rodent assemblages. However, the thermal maximum is recorded from $17.4 \mathrm{Ma}$ onward, coinciding with the increase in fauna related to tropical forest and wetter ecosystems, such as the glirid Vasseuromys (Suarez-Hernando, 2017) and the decrease in cricetids, coinciding with northward migration of the glirid key taxon Peridyromys murinus (Daams et al., 1997). Böhme (2003) described a similar pattern based on ectothermic vertebrates of central Europe and placed the onset of the warm and humid optimum between 18 and 16.5Ma.

Ostracods collected from the top of the outcropping T6/1 unit in the Loma Negra and Sancho Abarca sections by Martínez-García et al. (2014) include abundant specimens of Pseudocandona parallela. This species is characteristic of a stable lacustrine environment, reflecting deeper and cooler conditions, compared to the ephemeral ponds present within the T5 alluvial plain. These conditions are recorded between 16.1 and $15.5 \mathrm{Ma}$, coinciding with the maximum development of limestones within the Tudela Formation (Larrasoaña et al., 2006), which partly correlates to unit T6, and this interval records the maximum expansion of the lacustrine conditions in the Ebro Basin during the Neogene (Arenas and Pardo, 1999). These changes in water temperature and the presence of the glirid Vasseuromys in these deposits could indicate climate with strong seasonal variations (Martínez-García et al., 2014; Suarez-Hernando, 2017), which appears to be typical of the MMCO, together with an increase of humid ecosystems (Böhme, 2003; Diester-Haass et al., 2009). However, these statements need confirmation with further studies, e.g. based on stable isotopes.

\section{REMARKS AND CONCLUSIONS}

Stratigraphic and sedimentologic study of deposits in the T5 and T6 tectosedimentary units in the Plana de la Negra-Sancho Abarca area (western central sector of the Ebro Basin) has allowed i) construction of a sedimentary facies model, ii) analysis of sedimentary environments through space and time, and iii) an assessment of climatic and tectonic controls on sedimentation. The main highlights of this study are:

Five lithofacies have been characterized and mapped. The boundary between tectosedimentary units T5 and T6 has been established as a regional marker which represents the change from clastic to carbonate sedimentation.

17 sedimentary facies comprising carbonate, mixed and siliciclastic deposits have been recognised. These facies are stacked within 7 typical facies sequences (Facies Associations, FA) corresponding with deposition in three distinct environmental settings: distal alluvial, palustrine and lacustrine.

A sedimentary facies model for this succession envisages a laterally extensive alluvial plain intersected by low sinuosity bedload channels with lateral and terminal splays, and associated ephemeral freshwater ponds developed on the alluvial plain. Sedimentation of clastic facies is linked with deposition in the Luna fluvial system, at the Pyrenean (northern) basin margin. Further South, a large freshwater carbonate lake was developed, with fauna and flora indicating a typical depth of 2 to $4 \mathrm{~m}$. The lake was surrounded by wide palustrine fringes that underwent intermittent subaerial exposure.

Correlation with magnetostratigraphically and biostratigraphically dated sections nearby has allowed assignment of the Plana de la Negra-Sancho Abarca succession to the Burdigalian to Langhian (early Miocene to middle Miocene), corresponding to C5Dr to C5Br. The boundary between units T5 and T6 dated at 16.06-16.05Ma.

Unit T5/1 records deposition on a laterally extensive alluvial plain with fluvial channels and ephemeral palustrine ponds. This stage occurred during an overall retreat of alluvial inputs, with alluvial incursions within the lacustrine deposits favoured by low lake level conditions. Stage T5/2 records a gradual transition from distal alluvial to lacustrine-palustrine environments. 
Unit $\mathrm{T} 6 / 1$ is dominated by lacustrine and palustrine carbonates across the area and is interpreted to have been deposited during the maximum expansion of the lacustrine system associated with increasing humidity. T6/2 crops out only in the south and southeast of the area and reflects lowering lake level and fine grained clastic inputs from the north.

Regardless the contractional deformation in the Pyrenees (Guarga thrust unit) during the early to middle Miocene, the sedimentary evolution of the studied succession rather reflects the effects of climate changes, as was also inferred in central areas of the Ebro Basin.

The lacustrine expansion represented by the beginning of unit T6 is ascribed to a regional increase in humidity, which is interpreted to reflect the MMCO.

\section{ACKNOWLEDGMENTS}

This work was partly financed by Project CGL2013-42867 of the Spanish Government and European Regional Funds. This work is a contribution of the Geotransfer Research Group (Aragón Government, FEDER and the University of Zaragoza), and is also a contribution to the Group of the Basque Research Group System IT-930-16. We thank the Servicio de Preparación de Rocas y Materiales Duros (Servicio General de Apoyo a la InvestigaciónSAI) of the University of Zaragoza and the SGIKER of the University of the Basque Country for their technical support. N. Santos Bueno, FJ. Pérez Rivarés and J.C Larrasoaña are thanked for their help through field logistics and pertinent comments. Our gratitude to editor Dr. Garcés and reviewers Dr. Cabrera, Dr. Platt and Dr. Valero for their criticism and relevant ideas to improve the quality of this article.

\section{REFERENCES}

Agustí, J., Pérez-Rivarés, FJ., Cabrera, L., Garcés, M., Pardo, G., Arenas, C., 2011. The Ramblian-Aragonian boundary and its significance for the European Neogene continental chronology. Contributions from the Ebro Basin record (NE Spain). Geobios, 44, 121-134.

Alonso-Zarza, A.M., Calvo, J.P., García del Cura, M.A., 1992. Palustrine sedimentation and associated features grainification and pseudo-microkarst - in the Middle Miocene (Intermediate Unit) of the Madrid Basin, Spain. Sedimentary Geology, 76, 43-61.

Alonso-Zarza, A.M., Calvo, J.P, 2002. Tajo Basin. In: Gibbons, W., Moreno, T. (eds). The Geology of Spain. London, The Geological Society, 315-320.

Alonso-Zarza, A.M., 2003. Palaeoenvironmental significance of palustrine carbonates and calcretes in the geological record. Earth Science Reviews, 60, 261-298.
Alonso-Zarza, A.M., Meléndez, A., Martín-García, R., Herrero, M.J., Martín-Pérez, A., 2012. Discriminating between tectonism and climate signatures in palustrine deposits: lessons from the Miocene of the Teruel Graben, NE Spain. Earth Science Reviews, 113, 141-160.

Arasa-Tuliesa, A., Cabrera, L., 2018. Neogene-Quaternary onshore record in the lower Ebro river incised palaeovalley (Ebro margin, Catalan Coastal Range, NE Iberia). Geologica Acta, 16(3), 265-292.

Arenas, C., 1993. Sedimentología y paleogeografía del Terciario del margen pirenaico y sector central de la Cuenca del Ebro (zona aragonesa occidental). Doctoral Thesis. Universidad de Zaragoza, 858pp. Last accessed: March 2020. Website: https://zaguan.unizar.es/record/70725

Arenas, C., Fernández-Nieto, C., González-López, J.M., Pardo, G., 1993. Evolución mineralogical de los materiales miocenos de la Sierra de Alcubierre (sector central de la Cuenca del Ebro): Implicaciones en la evolución paleogeográfica. Boletín de la Sociedad Española de Mineralogía, 16, 51-64.

Arenas, C., Pardo, G., 1999. Latest Oligocene-Late Miocene lacustrine systems of the north-central part of the Ebro Basin (Spain): sedimentary facies model and palaeogeographic synthesis. Palaeogeography, Palaeoclimatology, Palaeoecology, $151,127-148$

Arenas, C., Alonso Zarza, A.M., Pardo, G., 1999. Dedolomitization and other early diagenetic processes in Miocene lacustrine deposits, Ebro Basin (Spain). Sedimentary Geology, 125, 23-45.

Arenas, C., Pardo, G., 2000. Neogene lacustrine deposits of the North-Central Ebro Basin, Northeastern Spain. In: Gierlowski-Kordesch, E.H., Kelts, K.R. (eds.). Lake Basins through Space and Time: American Association of Petroleum Geologists. Studies in Geology, 46, 395-406.

Arenas, C., Millán, H., Pardo, G., Pocoví, A., 2001. Ebro Basin continental sedimentation associated with late compressional Pyrenean tectonics (north-eastern Iberia): controls on basin margin fans and fluvial systems. Basin Research, 13, 65-89.

Armenteros, I., 1986. Estratigrafía y sedimentología del Neógeno del sector suroriental de la Depresión del Duero. Tesis Doctoral. Diputación de Salamanca, Serie Castilla y León $\mathrm{n}^{\mathrm{o}}$ 1, 471pp.

Armenteros, I., Daley, B., 1998. Pedogenic modification and structure evolution in palustrine facies as exemplified by the Bembridge Limestones (Late Eocene) of the Isle of Wight, southern England. Sedimentary Geology, 119, 275-295.

Astibia, H., Ginsburg, L., Janoo, A., Martínez, E., Murelaga, X., Pereda- Suberbiola, X., Sesé, C., 1995. Primeros datos sobre las faunas de tetrápodos fósiles del Terciario continental de las Bardenas Reales de Navarra (Depresión del Ebro). XI Jornadas de Paleontología, Tremp, 41-43.

Babault, J., Loget, N., Van Den Driessche, J., Castelltort, S., Bonnet, S., Day, P., 2006. Did the Ebro Basin connect to the Mediterranean before the Messinian salinity crisis? Geomorphology, 81, 155-165.

Barberà, X., Cabrera, L., Marzo, M., Parés, J.M., Agustí, J., 2001. A complete terrestrial Oligocene magnetobiostratigraphy from 
the Ebro Basin, Spain. Earth and Planetary Science Letters, 187, 1-16.

Bates, R.L., Jackson, J.A., 1985. Glossary of Geology. Alexandria, (VA, U.S.A.), American Geological Institute, 788pp.

Bohacs, K.M., Carrol, A.R., Neal, J.E., Mankiewicz, PJ., 2000. Lake basin type, source potential, and hydrocarbon character: an integrated sequence-stratigraphic geochemical framework. In: Gierlowski-Kordesch, E.H., Kelts, K.R. (eds.). Lake Basins through Space and Time: American Association of Petroleum Geologists. Studies in Geology, 46, 3-34.

Böhme, M., 2003. Miocene Climatic Optimum evidence from ectothermic vertebrates of Central Europe. Palaeogeography, Palaeoclimatology, Palaeoecology, 195, 389-401.

Brierley, G.J., 1996. Channel morphology and element assemblages: a constructivist approach to facies modeling. In: Carling, P.A., Dawson, M.R. (eds.). Advances in Fluvial Dynamics and Stratigraphy. New York, Wiley \& Sons, 263-298.

Cabrera, Ll., Sáez, A., 1987. Coal deposition in carbonaterich shallow lacustrine systems: the Calaf and Mequinenza sequences (Oligocene, eastern Ebro Basin, NE Spain). London, Journal of the Geological Society, 144, 451-461.

Calvo, J.P., Daams, R., Morales, J., López-Martínez, N., Agustí, J., Anadón, P., Armenteros, I., Cabrera, L., Civis, J., Corrochano, A., Díaz-Molina, M., Elízaga, E., Hoyos, M., Martín Suarez, E., Moissenet, E., Muñóz, A., Pérez-Garcia, A., Pérez-González, A., Portero, J.M., Robles, F, Ruiz-Bustos, A., Santisteban, C., Torres, T., van der Meulen, A.J., Vera, J.A., 1993. Up-to-date Spanish continental Neogene synthesis and paleoclimatic interpretation. Revista de la Sociedad Geológica de España, 6(3-4), 29-40.

Carroll, A.R., Bohacs, K.M., 1999. Stratigraphic classification of ancient lakes: Balancing tectonic and climatic controls. Geology, 27(2), 99-102.

Castiella, J., 1977. Mapa geológico de España, 1:50.000, sheet no. 320 (Tarazona de Aragón) and Memoir. Madrid, Instituto Geológico y Minero de España, 1 map, 23pp.

Clausing, A., Boy, J.A., 2000. Lamination and primary production in fossil lakes: relationship to palaeoclimate in the Carboniferous-Permian transition. In: Hart, M.B. (ed.). Climates: Past and Present. Journal of the Geological Society of London, 181, 5-16.

Costa, E., Garces, M., Lopez-Blanco, M., Beamud, E., Gomez-Paccard, M., Larrasoaña, J.C., 2010. Closing and continentalization of the South Pyrenean foreland basin (NE Spain): magnetochronological constraints. Basin Research, 22(6), 904-917.

Crusafont, M., Truyols, J., Riba, O., 1966. Contribución al conocimiento de la estratigrafía del Terciario continental de Navarra y Rioja. Notas y Comunicaciones del Instituto Geológico y Minero de España, 90, 53-76.

Daams, R., Freudenthel, M., 1988. Cricetidae (Rodentia) from the type Aragonian; the genus Megacricetodon. Biostratigraphy and palaaecology of the Neogene micromammalian faunas from the Calatayud-Teruel Basin (Spain). Scripta Geologica, 1 (Special Issue), 39-132.
Daams, R., Álvarez Sierra, M.Á., van der Meulen, A., PeláezCampomanes, P. 1997. Los micromamíferos como indicadores de paleoclimas y evolución de las cuencas continentales. In: Aguirre, E., Morales, J., Soria, D. (eds). Registros fósiles e Historia de la Tierra. Madrid, Editorial Complutense, 235-269.

Davis, S.J., Wiegand, B.A., Carrol, A.R., Chamberlain, C.P., 2008. The effect of dranage reorganization on paleoaltimetry studies: an example from the Paleogene Laramide foreland. Earth and Planetary Science Letters, 275, 258-268.

De Wet, C., Yocum, D.A., Mora, C., 1998. Carbonate lakes in closed basins: sensitive indicators of climate and tectonics: an example from the Gettysburg Basin (Triassic), Pennsylvania, USA. In: Stanley, K.W., McCabe, P.J. (eds.). Relative Role of Eustasy, Climate and Tectonism in Continental Rocks. SEPM, 59 (Special Publication), 191-209.

Diester-Haass, L., Billups, K., Gröcke, D.R., François, L., Lefebvre, V., Emeis, K.C., 2009. Mid-Miocene paleoproductivity in the Atlantic Ocean and implications for the global carbon cycle. Paleoceanography, 24, PA1209, 1-19.

Dunham, R.J., 1962. Classification of carbonate rocks according to depositional texture. In: Ham, W.E. (ed.). Classification of Carbonate Rocks. Tulsa, Memoir of the American Association of Petroleum Geologists, 1, 108-121.

Embry, A.F., Klovan, J.E., 1971. A late Devonian reef tract on northeastern Banks Island, NW Territories. Bulletin of Canadian Petroleum Geology, 19, 730-781.

Fisher, J.A., Nichols, G.J., Waltham, D.A., 2007. Unconfined flow deposits in distal sectors of fluvial distributary systems: Examples from the Miocene Luna and Huesca Systems, northern Spain. Sedimentary Geology, 195, 55-73.

Freytet, P., Plaziat, J.C., 1982. Continental carbonate sedimentation and pedogenesis - Late Cretaceous and Early Tertiary of Southern France. In: Purser, B.H. (ed.). Contributions to Sedimentology. Stuttgart: E. Schweizerbart, 12, 217pp.

García-Castellanos, D., Vergés, J., Gaspar-Escribano, J., Cloetingh, S., 2003. Interplay betwen tectonics, climate and fluvial transport during the Cenozoic evolution of the Ebro Basin (NE Iberia). Journal of Geophysical Research, 108(B7), 2347.

Gierlowki-Kordesch, E.H., Gómez-Fernández, J.C., Meléndez, N., 1991. Carbonate and coal deposition in an alluvial-lacustrine setting: Lower Cretaceous (Weald) in the Iberian Range (east-central Spain). In: Anadón, P., Cabrera, L., Kelts, K. (eds.). Lacustrine Facies Analysis. Special Publication of the International Association of Sedimentologists, 13, 109-125.

Gierlowski-Kordesch, E.H., 2010. Lacustrine carbonates. In: Alonso-Zarza, A.M., Tanner, L.H. (eds.). Carbonates in continental settings. Facies, Environments and Processes, Amsterdam, Developments in Sedimentology, 61, 1-101.

Glenn, C.R., Kelts, K., 1991. Sedimentary rhythms in lake deposits. In: Einsele, G., Ricken, W., Silacher, A. (eds.). Cycles and Events in Stratigraphy. New York, SpringerVerlag, 188-221.

González-Pardos, M., 2012. Carófitos del Mioceno inferior de la Formación Tudela (Cuenca del Ebro, Navarra). Master Thesis. Universitat de València, 68pp. 
Hirst, J.P.P, Nichols, G.J., 1986. Thrust tectonic controls on alluvial sedimentation patterns, southern Pyrenees. In: Allen, P.A., Homewood, P. (eds.). Foreland Basins. International Association of Sedimentologists Special Publication, 8, 153-164.

Inglès, M., Salvany, J.M., Muñoz, A., Pérez, A., 1998. Relationship of mineralogy to depositiona environments in the non-marine Tertiary mudstones of the southwestern Ebro Basin (Spain). Sedimentary Geology, 116, 159-176.

Kelts, K., Hsü, K.J., 1978. Freshwater carbonate sedimentation. In: Lerman, A. (ed.). Lakes: Chemistry, Geology, Physics. New York, Springer-Verlag, 295-324.

Kelts, K., Talbot, M., 1990. Lacustrine carbonates as geochemical archives of environmental change and biotic-abiotic interactions. In: Tilzer, M.M., Serruya, C. (eds.). Large lakes: ecological structure and function. Berlin, Springer-Verlag, 288-315.

Larena-Martin, Z., 2019. Estratigrafía y seidmentología del Mioceno de la Plana Negra-Sancho Abarca (sector centraloccidental de la Cuenca del Ebro). Master's Thesis. Universidad de Zaragoza, 60pp.

Larrasoaña, J.C., Murelaga, X., Garcés, M., 2006. Magnetobiochronology of Lower Miocene (Ramblian) continental sediments from the Tudela Formation (western Ebro basin, Spain). Earth and Planetary Science Letters, 243, 409-423.

Martín-Closas, C., Diéguez, C., 1998. Charophytes from the Lower Cretaceous of the Iberian Range (Spain). Palaeontology, 41(6), 1133-1152.

Martínez-García, B., Suarez-Hernando, O., Suárez-Bilbao, A., Pascual, A., Ordiales, A., Larrasoaña, J.C., Murelaga, X., Ruiz-Sánchez, FJ., 2014. Asociación de ostrácodos del Mioceno temprano-medio de Loma Negra (Bardenas Reales de Navarra, Cuenca del Ebro): evolución paleoambiental de un medio lacustre. Ameghiniana, 51(5), 405-419.

Meléndez, N., Liesa, C.L., Soria, A.R., Meléndez, A., 2009. Lacustrine system evolution during early rifting: El Castellar Formation (Galve sub-basin, Central Iberian Chain). Sedimentary Geology, 222, 64-77.

Miall, A.D., 1996. The Geology of Fluvial Deposits. Berlin, Springer, 582pp.

Millán, H., Pocoví, A., Casas, A., 1995. El frente de cabalgamiento surpirenaico en el extremo occidental de las Sierras Exteriores: sistemas imbricados y pliegues de despegue. Revista de la Sociedad Geológica de España, 8, 73-90.

Muñoz, A., Arenas, C., González, A., Luzón, A., Pardo, G., Pérez, A., Villena, J., 2002. Ebro Basin (northeastern Spain). In: Gibbons, W., Moreno, T. (eds.). The Geology of Spain. London, The Geological Society, 301-309.

Murelaga, X., Caballero, F, Rodriguez-Lázaro, J., Astibia, H., Pereda-Suberbiola, X., 1997. Análisis preliminar de los ostrácodos del Mioceno inferior de las Bardenas Reales de Navarra (Cuenca del Ebro). Geogaceta, 22, 192-132.

Murelaga, X. 2000. Estudio de las faunas de vertebrados del Mioceno inferior de las Bardenas Reales de Navarra y áreas colindantes (Cuenca del Ebro, Navarra). Doctoral Thesis. Universidad del País Vasco/Euskal Herriko Unibertsitatea, 363pp.

Murelaga, X., Pereda Suberbiola, X., de Lapparent de Broin, F., Rage, J.-C., Duffaud, S., Astibia, H., Badiola, A., 2002. Amphibians and reptiles from the Early Miocene of the Bardenas Reales of Navarre (Ebro Basin, Iberian Peninsula). Geobios, 35, 347-365.

Murelaga, X., Pérez-Rivarés, FJ., Vázquez-Urbez, M., Zuluaga, M.C., 2008. Nuevos datos bioestratigráficos y paleoecológicos del Mioceno medio (Aragoniense) del área de Tarazona de Aragón (Cuenca del Ebro, provincial de Zaragoza, España). Ameghiniana, 45, 393-406.

Navarro-Jiménez, J.I., Navarro-Luna, J., Muñoz-Jiménez, A., 2011. Análisis Tectosedimentario de la región de Bradenas Reales, Cuenca del Ebro (Aragón-Navarra). Reunión Grupo Español del Terciario, resumen (unpublished), 4pp.

Nichols, G.J., Fisher, J.A., 2007. Processes, facies and architecture of fluvial distributary system deposits. Sedimentary Geology, 195, 75-90.

Ogg, J.G., 2012. Geomagnetic Polarity Time Scale. In: Gradstein, F.M., Ogg, J.G., Schmitz, M.D., Ogg, G.M. (eds.). The Geologic Time Scale 2012. Boston, Elsevier, 85-113.

Oliva-Urcia, B., Beamud, E., Arenas, C., Pueyo, E.L., Garcés, M., Soto, R., Valero, L., Pérez-Rivarés, FJ., 2019. Dating the northern deposits of the Ebro foreland basin; implications for the kinematics of the SW Pyrenean front. Tectonophysics, 765, 11-34.

Pardo, G., Villena, J., González, A., 1989. Contribución a los conceptos y a la aplicacion del anáisis tectosedimentarias. Rupturas y unidades tectosedimentarias como fundamento de correlaciones estratigráficas. Revista de la Sociedad Geológica de España, 2(3-4), 199-221.

Pardo, G., Arenas, C., González, A., Luzón, A., Muñoz, A., Pérez, A., Pérez-Rivarés, FJ., Vázquez-Úrbez, M., Villena, J., 2004. La Cuenca del Ebro. In: Vera, J.A. (eds.). Geología de España. Madrid, Revista de la Sociedad Geológica de España-Instituto Geológico y Minero de España, 533-543.

Paredes, J.M., Foix, N., Colombo Piñol, F, Nillni, A., Allard, J.O., Marquillas, R.A., 2007. Volcanic and climatic controls on fluvial style in a high-energy system: the Lower Cretaceous Matasiete Formation, Golfo San Jorge Basin, Argentina. Sedimentary Geology, 202, 96-123.

Pérez, A., 1989. Estratigrafía y sedimentología del Terciario del borde meridional de la Depresión del Ebro (sector RiojanoAragonés) y cubetas de Muniesa y Montalbán. Doctoral Thesis. Universidad de Zaragoza, unpublished, 525pp.

Pérez-Rivarés, FJ., 2016. Studio magnetoestratigráfico del Mioceno del sector central de la Cuenca del Ebro: Cronología, correlación y análisis de la ciclicidad sedimentaria. Doctoral Thesis. Universidad de Zaragoza, 281pp.

Pérez-Rivarés, FJ., Arenas, C., Pardo, G., Garcés, M., 2018. Temporal aspects of genetic stratigraphic units in continental sedimentary basins: Examples from the Ebro Basin, Spain. Earth Science Reviews, 178, 136-153. 
Pettijohn, F., Potter, P.E., Siever, R., 1973. Sand and sandstones. New York-Heidelberg-Berlin, Springer-Verlag, 618pp.

Platt, N.H., 1989. Lacustrine carbonates and pedogenesis: sedimentology and origin of palustrine deposits from the Early Cretaceous Rupelo Formation, W Cameros Basin, N Spain. Sedimentology, 36, 665-684.

Platt N.H., Wright, V.P., 1991. Lacustrine carbonates: facies models, facies distributions and hydrocarbons aspects. In: Anadón, P., Cabrera, L., Kelts, K. (eds.). Lacustrine Facies Analysis. Special Publication of the International Association of Sedimentologists, 13, 57-74.

Platt, N.H., Wright, V.P., 1992. Palustrine carbonates and the Florida Everglades: towards an exposure index for the freshwater environment. Journal of Sedimentary Petrology, 62, 1058-1071.

Platt, N.H., Pujalte, V. 1994. Correlation of Upper Jurassic-Lower Cretaceous continental sequences from the southern Biscay margin, northern Spain. London, Journal of the Geological Society, 151, 715-726.

Platt, N.H., 1995. Sedimentation and tectonics of a synrift succession: Upper Jurassic alluvial fans and palaeokarst at the Cimmerian unconformity, western Cameros Basin, northern Spain. Special Publication of the International Association of Sedimentologists, 22, 219-236.

Plaziat, J.C., Freytet, P., 1978. Le pseudomicrokarst pédologique: un aspect particulier des paleo-pedogenèses dévelopées sur les dépôts calcaires lacustres dans le Tertiaire de Languedoc. Paris, Comptes Rendus de l'Académie des Sciences, 286, 1661-1664.

Porter, R.J., Gallois, R.W., 2008. Identifying fluvio-lacustrine intervals in thick playa-lake successions: an integrated sedimentology and ichnology of arenaceous members in the mid-Late Triassic Mercia Mudstone Group of southwest England UK. Palaeogeography, Palaeoclimatology, Palaeoecology, 270, 381-398.

Quijada, I.E., Suarez-Gonzalez, P., Benito, M.I., Mas, R., 2013. Depositional depth of laminated carbonate deposits: insights from the Lower Cretaceous Valdeprado Formation (Cameros Basin, Northern Spain). Journal of Sedimentary Research, 83, 241-257.

Quijada, I.M., 2014. Evolución sedimentaria y paleogeográficas de los sistemas costeros silicicl'sticos y cartonático-evaporíticos del Grupo Oncala (Berriasiense, Cuenca de Cameros oriental). Doctoral Thesis. Universidad Complutense de Madrid, 362pp.

Riba, O., 1955. Sobre la edad de los conglomerados terciarios del borde Norte de las Sierras de la Demanda y de Cameros. Notas y Comunicaciones del Instituto Geológico y Minero de España, 39, 39-50.

Riba, O., Reguant, S., Villena, J., 1983. Ensayo de síntesis estratigráfica y evolutiva de la cuenca terciaria del Ebro. In: Comba, J.A. (coord.). Geología de España, Libro Jubilar J.M. Ríos. Instituto Geológico y Minero de España, 131-159.

Ruiz-Sánchez, FJ., Murelaga, X., Freudenthal, M., Larrasoaña, J.C., Furió, M., Garcés, M., González-Pardos, M., SuarezHernando, O., 2012. Rodents and insectivores from the
Lower Miocene (Agenian and Ramblian) of the Tudela Formation (Ebro Basin, Spain). Journal of Iberian Geology, 38(2), 349-372.

Ruiz-Sánchez, FJ., Murelaga, X., Freudenthal, M., Larrasoaña, J.C., Furió, M., Garcés, M., González-Pardos, M., SuarezHernando, O., 2013. Micromammalian faunas from the Middle Miocene (Middle Aragonian) of the Tudela Formation (Ebro Basin, Spain). Bulletin of Geosciences, 88, 131-152.

Sáez, A., Valero-Garcés, B.L., Moreno, A., Bao, R., Pueyo, J.J., González-Sampériz, P., Giralt, S., Taberner, C., Herrera, C., Gibert, R.O, 2007a. Lacustrine sedimentation in active volcanic settings: The Late Quaternary depositional evolution of Lake Chungará (northern Chile). Sedimentology, 54, 1191-1222.

Sáez, A., Anadón, P., Herrero, M.J., Moscariello, A., 2007 b. Variable style of transition between Palaeogene fluvial fan and lacustrine systems, southern Pyrenean foreland, NE Spain. Sedimentology, 54, 367-390.

Scott, J.J., Smith, M.E., 2015. Trace fossils of the Eocene Green River Lake Basins, Wyoming, Utah and Colorado. In: Smith, M.E., Carroll, A.R. (eds.). Stratigraphy and Paleolimnology of the Green River Formation, Western USA, Syntheses in Limnogeology, 1. Springer Science \& Business Media Dordrech, 313-350.

Soler, M., Puigdefábregas, C., 1970. Líneas generals de la geología del Alto Aragón Occidental. Pirineos, 96, 5-20.

Soulié-Märsche, I., Bieda, S., Lafond, R., Maley, J., Baitoudji, M', Vincent, P.M., Faure, H., 2010, Charophytes as bio-indicators for lake level high stand at "Trou au Natron", Tibesti, Chad, during the Late Pleistocene. Global and Planetary Change, 72, 334-340. DOI: 10.1016/j.gloplacha.2010.05.004

Suarez-Hernando, O., 2017. Magnetobiocronología y Paleoecología del Mioceno inferior-medio en las Bardenas Reales de Navarra (Cuenca del Ebro). Doctoral Thesis. Universidad del País Vasco/Euskal Herriko Unibertsitatea, $315 \mathrm{pp}$.

Tanner, L.H., 2000. Palustrine-lacustrine and alluvial facies of the (Norian) Owl Rock Formation (Chinle Group), Four Corners Region, Southwestern U.S.A.: implications for Late Triassic paleoclimate. Journal of Sedimentary Research, 70, 1280-1289.

Valero, L., Garcés, M., Cabrera, L., Costa, E., Sáez, L., 2014. 20 Myr of eccentricity paced lacustrine cycles in the Cenozoic Ebro Basin. Earth and Planetary Science Letters, 408, 183-193.

van der Meulen, A.J., García-Paredes, I., Álvarez-Sierra, M.Á., van den Hoek Ostende, L.W., Hordijk, K., Oliver, A., PeláezCampomanes, P., 2012. Updated Aragonian biostratigraphy: Small mammal distribution and its implications for the Miocene European Chronology. Geologica Acta, 10(2), 159-179.

Vázquez-Urbez, M., Arenas, C., Pardo, G., 2003. Isotopic characterization $(\delta 13 \mathrm{C}$ and $\delta 18 \mathrm{O})$ of Miocene continental carbonate deposits of the western Ebro Basin (Spain). Tucson (Arizona), Third International Limnogeological Congress, Abstracts, 306-307. 
Vázquez-Urbez, M., Arenas, C., Pardo, G., Pérez-Rivarés, J., 2013. The effect of drainage reorganization and climate on the sedimentologic evolution of intermontane lake systems: the final fill stage of the Tertiary Ebro Basin (Spain). Journal of Sedimentary Research, 83, 562-590.

Wright, V.P., 1990. Lacustrine carbonates. In: Tucker, M.E., Wright, V.P. (eds.). Carbonate sedimentology, chapter 4.4. Oxford, Blackwell Science Ltd., 161-190.
Zachos, J., Pagano, M., Sloan, L., Thomas, E., Billups, K., 2001. Trends, rhythms and aberrations in global climate from $65 \mathrm{Ma}$ to Present. Science, 269, 686-693.

Zachos, J.C., Dickens, G.R., Zeebe, R.E., 2008. An early Cenozoic perspective on greenhouse warming and carbon-cycle dynamics. Nature, 451(17), 279-283.

Manuscript received December 2019;

revision accepted April 2020;

published Online May 2020. 


\section{APPENDIX I}

TABLE I. Characteristics and interpretation of sedimentary facies in the studied area

\begin{tabular}{|c|c|c|c|c|c|c|c|c|}
\hline \multirow{2}{*}{$\begin{array}{l}\text { Facies } \\
\text { (Figures) }\end{array}$} & \multicolumn{2}{|c|}{$\begin{array}{l}\text { Occurrence and relative } \\
\text { abundance }\end{array}$} & \multirow[t]{2}{*}{ Stratigraphic features } & \multirow{2}{*}{$\begin{array}{l}\text { Textural characteristics, } \\
\text { microstructure and components }\end{array}$} & \multirow{2}{*}{$\begin{array}{l}\text { Sedimentary and } \\
\text { diagenetic features }\end{array}$} & \multirow{2}{*}{$\begin{array}{l}\text { Identifiable } \\
\text { biological } \\
\text { content }\end{array}$} & \multirow{2}{*}{$\begin{array}{l}\text { Facies } \\
\text { association }\end{array}$} & \multirow{2}{*}{$\begin{array}{l}\text { Depositional sedimentary context } \\
\text { (+Relevant References) }\end{array}$} \\
\hline & North sector & South sector & & & & & & \\
\hline \multicolumn{9}{|c|}{ Carbonate facies } \\
\hline \multicolumn{9}{|c|}{ Massive limestones (Lm) (Fig. 6A) } \\
\hline $\begin{array}{l}\text { Ostracod and } \\
\text { charophyte } \\
\text { Mudstone- } \\
\text { Wackestone } \\
\\
\text { Lmo } \\
\text { Fig. 7B } \\
\end{array}$ & - & - & $\begin{array}{c}\text { Tabular strata, } 15 \text { to } \\
40 \mathrm{~cm} \text { thick and some } \\
\mathrm{m} \text { in lateral extent. } \\
\text { Irregular bases and flat } \\
\text { tops }\end{array}$ & $\begin{array}{l}\text { Mudstone-Wackestone with } \\
\text { sparse bioclastic content. }\end{array}$ & $\begin{array}{l}\text { Fenestral porosity. } \\
\text { Sparse bioturbation } \\
\text { traces. Weak-moderate } \\
\text { compaction. }\end{array}$ & $\begin{array}{l}\text { Ostracods and } \\
\text { minor } \\
\text { charophyte } \\
\text { remains } \\
\text { (gyrogonites } \\
\text { and thalli } \\
\text { fragments). } \\
\text { Very sparse } \\
\text { bivalve shells. }\end{array}$ & FA7. & $\begin{array}{l}\text { Protected, low energy and } \\
\text { relatively deep lake areas, with } \\
\text { photic conditions where } \\
\text { organisms such as ostracods } \\
\text { and charophytes lived } \\
\text { (Gierlowski-Kordesch, 2010; } \\
\text { Vázquez-Urbez, 2013). }\end{array}$ \\
\hline $\begin{array}{l}\text { Charophyte } \\
\text { Wackestone- } \\
\text { Packstone } \\
\text { Lmc }\end{array}$ & & 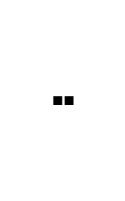 & $\begin{array}{l}\text { Tabular strata, } 10 \text { to } \\
25 \mathrm{~cm} \text { thick and } 10 \text { 's } \mathrm{m} \\
\text { in lateral extent. Flat } \\
\text { bases and tops }\end{array}$ & $\begin{array}{l}\text { Wackestone-Packstone with } \\
\text { sparse to abundant bioclastic } \\
\text { content. Bioclasts locally. They } \\
\text { are grouped in "irregular masses" } \\
\text { at various levels. }\end{array}$ & $\begin{array}{l}\text { Structureless. Very } \\
\text { sparse bioturbation } \\
\text { traces. Weak-moderate } \\
\text { compaction (bioclast } \\
\text { flattening and } \\
\text { breakage). Rare calcite } \\
\text { spar-microspar fills. } \\
\text { Weak neomorphism. }\end{array}$ & $\begin{array}{l}\text { Chrophytes } \\
\text { (thalli } \\
\text { fragments and } \\
\text { gyrogonites). }\end{array}$ & FA3. & $\begin{array}{c}\text { Relatively calm, photic lacustrine } \\
\text { areas with extensive charophyte } \\
\text { "meadows" (Margalef, 1983; } \\
\text { Vázquez-Urbez, 2013; González- } \\
\text { Pardos, 2012). }\end{array}$ \\
\hline \multicolumn{9}{|l|}{ Figs. $8 \mathrm{~A}, 8 \mathrm{~B}$} \\
\hline $\begin{array}{c}\text { Bioclastic } \\
\text { Wackestone } \\
\text { Lmb }\end{array}$ & $m$ & 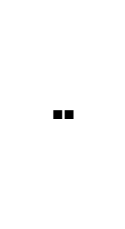 & $\begin{array}{l}\text { Tabular strata, } 30 \mathrm{~cm} \text { to } \\
1.2 \mathrm{~m} \text { thick and } 10 \text { 's } \mathrm{m} \\
\text { in lateral extent. Flat } \\
\text { bases and flat or } \\
\text { irregular tops. }\end{array}$ & $\begin{array}{c}\text { Bioclastic wackestone, } \\
\text { occasionally packstone. Sparse } \\
\text { bioclast and small quartz grains. }\end{array}$ & $\begin{array}{l}\text { Fenestral, mouldic and } \\
\text { occasional shelter } \\
\text { porosity. Weak- } \\
\text { moderate compaction. } \\
\text { Calcite spar-microspar } \\
\text { fills. Weak } \\
\text { neomorphism. }\end{array}$ & $\begin{array}{l}\text { Varied } \\
\text { bioclasts: } \\
\text { ostracods, } \\
\text { charophytes } \\
\text { and fragments } \\
\text { of gastropod } \\
\text { and bivalve } \\
\text { shells. }\end{array}$ & $\begin{array}{l}\mathrm{FA} 2,3,4,5,6 \\
\quad \text { and } 7 \text {. }\end{array}$ & $\begin{array}{l}\text { Shallow lake areas with } \\
\text { permanent water level where } \\
\text { various organisms lived; } \\
\text { occasional inflows of higher } \\
\text { energy currents that transported } \\
\text { both bioclasts and quartz grains } \\
\text { (Alonso-Zarza and Wright, 2010; } \\
\text { Sturm and Matter, 1978; Platt, } \\
\text { 1989; Platt and Wright, 1992). }\end{array}$ \\
\hline $\begin{array}{l}\text { Intraclast, peloid } \\
\text { and bioclast } \\
\text { Packstone }\end{array}$ & $m$ & 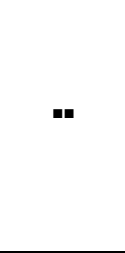 & $\begin{array}{l}\text { Tabular strata, } 20 \text { to } \\
30 \mathrm{~cm} \text { thick and } 10 \text { 's } \mathrm{m} \\
\text { in lateral extent. Flat } \\
\text { and irregular bases } \\
\text { and tops. }\end{array}$ & $\begin{array}{c}\text { Poorly sorted packstone. Irregular } \\
\text { to subspherical intraclasts }(0.4- \\
1.2 \mathrm{~mm} \text { in diameter). } \\
\text { Subspherical peloids }(0.03- \\
0.42 \mathrm{~mm} \text { in diameter). Small } \\
\text { gastropod shells and very sparse } \\
\text { fragments of bivalves and } \\
\text { charophytes. }\end{array}$ & $\begin{array}{l}\text { Structureless. Empty } \\
\text { mouldic porosity after } \\
\text { partial-complete } \\
\text { allochem dissolution. } \\
\text { Weak-moderate } \\
\text { compaction. Some } \\
\text { calcite spar-microspar } \\
\text { fills. Partial matrix } \\
\text { neomorphism. }\end{array}$ & $\begin{array}{l}\text { Fragments of } \\
\text { gastropods } \\
\text { and bivalves, } \\
\text { some } \\
\text { fragments of } \\
\text { charophytes. }\end{array}$ & FA6. & $\begin{array}{l}\text { Erosion of lake carbonate } \\
\text { deposits and resedimentation in } \\
\text { relatively energetic shallow } \\
\text { lacustrine areas (Platt, 1989). }\end{array}$ \\
\hline \multicolumn{9}{|l|}{$\begin{array}{l}\text { Intraclastic and } \\
\text { bioclastic }\end{array}$} \\
\hline $\begin{array}{l}\text { Wackestone- } \\
\text { Packstone }\end{array}$ & $m$ & 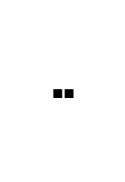 & $\begin{array}{l}\text { Tabular strata, } 20 \text { to } \\
60 \mathrm{~cm} \text { thick and } 10 \text { 's } \mathrm{m} \\
\text { in lateral extent. Flat } \\
\text { and irregular bases } \\
\text { and tops. }\end{array}$ & $\begin{array}{l}\text { Intraclastic and bioclastic } \\
\text { wackestone-packstone. } \\
\text { Subangular micritic intraclasts, } \\
\text { between } 0.1 \mathrm{~mm} \text { to } 1.2 \mathrm{~cm} \text { in } \\
\text { diameter. Subangular quartz } \\
\text { grains of milimetric size, } \\
\text { dispersed in the matrix. }\end{array}$ & $\begin{array}{l}\text { Structureless. Sparse } \\
\text { mouldic porosity, empty } \\
\text { or with calcite spar } \\
\text { infills. Weak-moderate } \\
\text { compaction. Rare } \\
\text { bioturbation traces. }\end{array}$ & $\begin{array}{l}\text { Fragments of } \\
\text { ostracods and } \\
\text { charophytes,pl } \\
\text { us small } \\
\text { amounts of } \\
\text { bivalve } \\
\text { fragments. }\end{array}$ & FA6. & $\begin{array}{c}\text { Shallow, relatively energetic lake } \\
\text { areas with occasional inflows of } \\
\text { higher energy currents carrying } \\
\text { bioclasts, intraclasts and small } \\
\text { quartz grains (Sturm and Matter, } \\
\text { 1978; Platt, 1989). }\end{array}$ \\
\hline Figs. 8D & & & & & & & & \\
\hline
\end{tabular}


TABLE I. Continued.

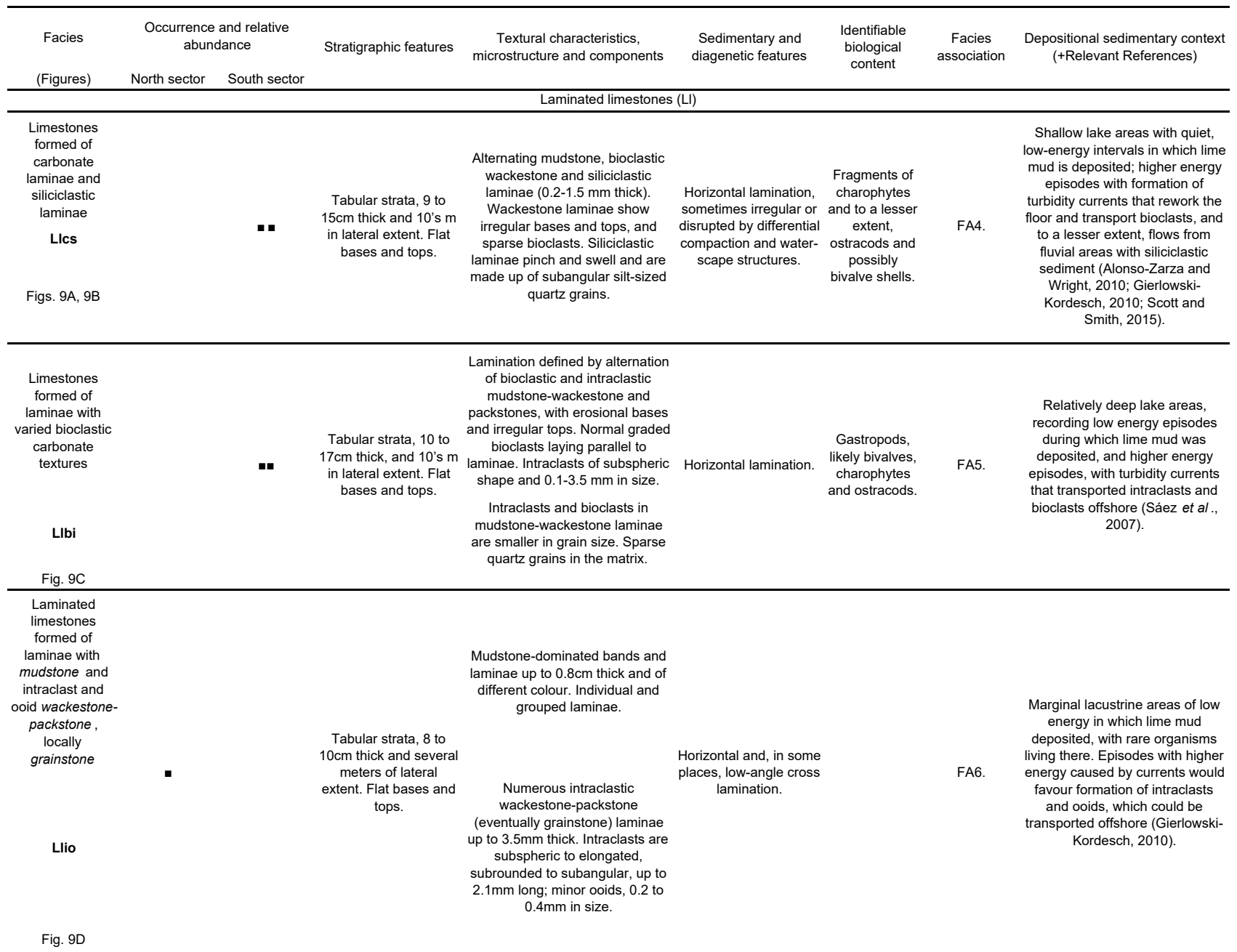

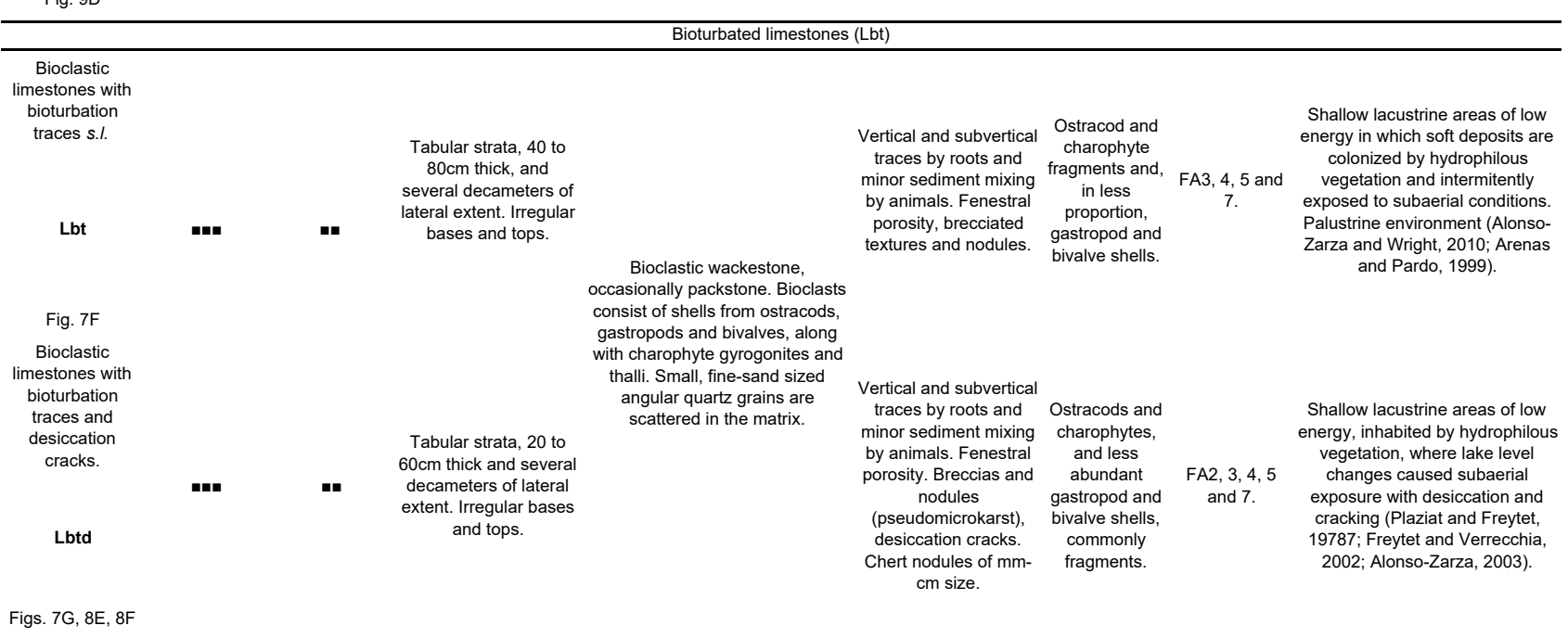


TABLE I. Continued.

\begin{tabular}{|c|c|c|c|c|c|c|c|c|}
\hline \multirow{2}{*}{$\begin{array}{c}\text { Facies } \\
\text { (Figures) } \\
\end{array}$} & \multicolumn{2}{|c|}{$\begin{array}{l}\text { Occurrence and relative } \\
\text { abundance }\end{array}$} & \multirow[t]{2}{*}{ Stratigraphic features } & \multirow{2}{*}{$\begin{array}{l}\text { Textural characteristics, } \\
\text { microstructure and components }\end{array}$} & \multirow{2}{*}{$\begin{array}{l}\text { Sedimentary and } \\
\text { diagenetic features }\end{array}$} & \multirow{2}{*}{$\begin{array}{c}\text { Identifiable } \\
\text { biological } \\
\text { content }\end{array}$} & \multirow{2}{*}{$\begin{array}{c}\text { Facies } \\
\text { association }\end{array}$} & \multirow{2}{*}{$\begin{array}{l}\text { Depositional sedimentary context } \\
\text { (+Relevant References) }\end{array}$} \\
\hline & North sector & South sector & & & & & & \\
\hline \multicolumn{9}{|c|}{ Mixed facies } \\
\hline Laminated marls & - & - & $\begin{array}{l}\text { Tabular strata, } 10 \mathrm{~cm} \text { to } \\
60 \mathrm{~m} \text { thick, and } \\
\text { decameters to } \\
\text { hectometers of lateral } \\
\text { extent. Flat bases and } \\
\text { tops. }\end{array}$ & $\begin{array}{l}\text { Siliciclastic sediment (clay- } \\
\text { minerals, silt-size quartz grains) } \\
\text { and calcite mud. Some laminae } \\
\text { are rich in calcite and others in } \\
\text { quartz grains. } \\
\text { In general, they contain ostracod } \\
\text { and charophyte fragments, and } \\
\text { rare carbonaceous plant debris } \\
\text { and shell fragments. }\end{array}$ & $\begin{array}{l}\text { Horizontal lamination, } \\
\text { giving by different } \\
\text { colour and/or grain-size } \\
\text { or quartz content } \\
\text { differences between } \\
\text { laminae. Occasionally, } \\
\text { bioturbation produced } \\
\text { by root traces and } \\
\text { other benthic } \\
\text { organisms. }\end{array}$ & $\begin{array}{l}\text { Ostracod and } \\
\text { charophyte } \\
\text { fragments.. }\end{array}$ & $\begin{array}{l}\mathrm{FA} 3,4,5,6 \\
\text { and } 7 .\end{array}$ & $\begin{array}{l}\text { Lacustrine areas, always under } \\
\text { permanent water column, that } \\
\text { received fine-sized siliciclastic } \\
\text { sediment and bioclasts. During } \\
\text { waning level, calm areas } \\
\text { inhabited by ostracods and } \\
\text { charophytes, with occasional } \\
\text { colonization by subaquatic plants } \\
\text { (Arenas and Pardo, 1999; Scott } \\
\text { and Smith, 2015). }\end{array}$ \\
\hline
\end{tabular}

\begin{tabular}{|c|c|c|c|c|c|c|c|c|}
\hline $\begin{array}{l}\text { Massive marls } \\
\qquad \mathrm{Mm} \\
\text { Fig. } 7 \mathrm{~B}\end{array}$ & $m$ & $m$ & $\begin{array}{c}\text { Tabular stata, } 30 \mathrm{~cm} \text { to } \\
3.7 \mathrm{~m} \text { thick, and several } \\
\text { decameters of lateral } \\
\text { extent. Flat bases and } \\
\text { tops. }\end{array}$ & $\begin{array}{l}\text { Siliciclastic sediment (clay- } \\
\text { minerals, silt-size quartz grains) } \\
\text { and calcite mud. Scattered } \\
\text { bioclasts. }\end{array}$ & $\begin{array}{l}\text { Physical structures are } \\
\text { absent. Only present } \\
\text { abundant root traces } \\
\text { (bioturbation). }\end{array}$ & & $\begin{array}{c}\mathrm{FA} 2,3,4,5,6 \\
\text { and } 7 .\end{array}$ & $\begin{array}{l}\text { Palustrine environment. Shallow } \\
\text { water with hydrophilous } \\
\text { vegetation, possibly developed } \\
\text { as a result of shallowing of } \\
\text { offshore areas in which fine } \\
\text { siliclastics deposited during water } \\
\text { inputs (Armenteros et al, 2002; } \\
\text { Arenas and Pardo, 1999). }\end{array}$ \\
\hline \multicolumn{9}{|c|}{ Clastic facies } \\
\hline \multicolumn{9}{|c|}{ Sandstones (S) } \\
\hline $\begin{array}{c}\text { Massive } \\
\text { sandstones } \\
\quad \mathrm{Sm} \\
\text { Figs. 10D, 10E, } \\
\text { 11B, 11C }\end{array}$ & $m$ & $m$ & $\begin{array}{l}\text { Tabular strata, } 15 \text { to } \\
40 \mathrm{~cm} \text { thick and several } \\
\text { meters of lateral } \\
\text { extent. Flat bases and } \\
\text { tops. }\end{array}$ & $\begin{array}{l}\text { Sublithoarenites, clast supported, } \\
\text { formed principally of quartz and } \\
\text { less abundant carbonate grains. } \\
\text { Carbonate matrix. Rare reworked } \\
\text { foraminifers. }\end{array}$ & Structureless & $\begin{array}{l}\text { Rare reworked } \\
\text { foraminifers }\end{array}$ & FA2. & $\begin{array}{l}\text { Sand deposition from unconfined } \\
\text { tractive currents that deposit } \\
\text { sand load rapidly, without } \\
\text { generating internal structures } \\
\text { (Vázquez-Urbez et al ., 2013. }\end{array}$ \\
\hline $\begin{array}{l}\text { Sandstones with } \\
\text { horizontal and } \\
\text { cross lamination }\end{array}$ & & & & $\begin{array}{l}\text { Sublithoarenites, clast supported, } \\
\text { formed principally of quartz and } \\
\text { less abundant carbonate grains. } \\
\text { Carbonate matrix. }\end{array}$ & & & & \\
\hline $\mathrm{Sh}, \mathrm{Sr}$ & $m$ & - & $\begin{array}{l}\text { Tabular strata, up to } \\
1.3 \mathrm{~m} \text { thick and several } \\
\text { meters of lateral } \\
\text { extent. Irregular and } \\
\text { erosional bases and } \\
\text { flat tops. }\end{array}$ & $\begin{array}{l}\text { Different proportions of silt-size or } \\
\text { variable size of quartz grains } \\
\text { produce lamination. Include shell } \\
\text { fragments that are aligned } \\
\text { parallel to lamination. }\end{array}$ & $\begin{array}{l}\text { Horizontal and cross- } \\
\text { lamination. } \\
\text { Occasionally, fining } \\
\text { upward evolution. }\end{array}$ & $\begin{array}{l}\text { Shell } \\
\text { fragments, } \\
\text { probably of } \\
\text { gastropods } \\
\text { and bivalves. }\end{array}$ & FA1 and 2. & $\begin{array}{l}\text { Sand deposition from expansive } \\
\text { or unconfined flows in fluvial } \\
\text { environment, formed at the distal } \\
\text { termination of channels or } \\
\text { generated as channel overbanks } \\
\text { (Brierley, 1996; Fisher et al., } \\
\text { 2007; Paredes et al ., 2007). }\end{array}$ \\
\hline
\end{tabular}

Figs. 10C, 10F

\begin{tabular}{|c|c|c|c|c|c|c|c|c|}
\hline $\begin{array}{l}\text { Sandstones with } \\
\text { trough cross } \\
\text { stratification } \\
\text { St } \\
\text { Fig. 10B }\end{array}$ & m & - & $\begin{array}{l}\text { Channel-shaped } \\
\text { bodies in cross } \\
\text { sections (convex-flat } \\
\text { and convex-convex } \\
\text { shapes) with erosional } \\
\text { bases and irregular } \\
\text { tops, up to } 2 \mathrm{~m} \text { thick } \\
\text { and meters to } \\
\text { decameters wide. }\end{array}$ & $\begin{array}{l}\text { Sublithoarenites, clast supported, } \\
\text { formed principally of quartz and } \\
\text { less abundant carbonate grains. } \\
\text { Carbonate matrix. }\end{array}$ & $\begin{array}{c}\text { Trough cross- } \\
\text { stratification forming } \\
\text { lenticular sets, } \\
\text { decimeter in thickness. }\end{array}$ & $\begin{array}{l}\text { Shell } \\
\text { fragments, } \\
\text { probably of } \\
\text { gastropods } \\
\text { and bivalves. }\end{array}$ & FA1 and (2). & $\begin{array}{l}\text { Sand deposition in low sinuosity } \\
\text { channels of high energy, with } \\
\text { development of sand bars or } \\
\text { dunes in fluvial environment } \\
\text { (Miall, 1996; Porter and Gallois, } \\
\text { 2008). }\end{array}$ \\
\hline \multicolumn{9}{|c|}{ Mudstones $(\mathrm{F})$} \\
\hline $\begin{array}{c}\begin{array}{c}\text { Mudstones with } \\
\text { horizontal } \\
\text { lamination and/or } \\
\text { bioturbation }\end{array} \\
\text { Fh y Fhbt } \\
\text { Figs. } 10 \mathrm{D}, 10 \mathrm{G}, \\
11 \mathrm{~A}, 11 \mathrm{~B}\end{array}$ & $m$ & $m$ & $\begin{array}{l}\text { Tabular beds up to } 5 \mathrm{~m} \\
\text { thick and several } \\
\text { decameters of lateral } \\
\text { extent. Irregular bases } \\
\text { and tops. }\end{array}$ & $\begin{array}{l}\text { Silt- and clay-size particles of } \\
\text { varied composition (siliceous and } \\
\text { carbonate). Successive laminae } \\
\text { contain variable amount of silt } \\
\text { and fine sand producing } \\
\text { horizontal lamination. }\end{array}$ & $\begin{array}{l}\text { Horizontal and } \\
\text { occasional convoluted } \\
\text { laminations. Vertical } \\
\text { traces of bioturbation. }\end{array}$ & & FA2 and (1). & $\begin{array}{l}\text { Distal alluvial plains that receive } \\
\text { mud and sand sediment during } \\
\text { floodings, i.e, flood plain deposits } \\
\text { (Tanner, 2000). }\end{array}$ \\
\hline $\begin{array}{c}\text { Massive } \\
\text { mudstones, at } \\
\text { places with } \\
\text { bioturbation } \\
\text { Fm y Fmbt } \\
\text { Figs. 10B, 10C, } \\
\text { 10E, 11D }\end{array}$ & II & $m$ & $\begin{array}{l}\text { Tabular beds up to } 8 \mathrm{~m} \\
\text { thick and decameters } \\
\text { to hectometers of } \\
\text { lateral extent. Irregular } \\
\text { bases and tops. }\end{array}$ & $\begin{array}{l}\text { Silt- and clay-size particles of } \\
\text { varied composition (siliceous and } \\
\text { carbonate). }\end{array}$ & $\begin{array}{l}\text { Structureless or with } \\
\text { vertical root traces. }\end{array}$ & & FA1 and 2. & $\begin{array}{l}\text { Distal alluvial plain deposits that } \\
\text { remain subaerially exposed over } \\
\text { long periods of time, with } \\
\text { occasional colonization by plants, } \\
\text { and liable to oxidation (Paredes } \\
\text { et al., 2007; Porter and Gallois, } \\
\text { 2008; Scott and Smith, 2015). }\end{array}$ \\
\hline
\end{tabular}

- Common ... Abundant 